SDemoirs of the SDuscum of Comparatine Zoöloge

A'T II ARYARI) COLLE(AE.

Vor. XI. No. 1.

\title{
SOLENODON PARADOXUS.
}

BY

GLOVER MI. ALLEN.

With Nine Plates.

CAMBRIDGE, U. S. A.:

printeo for the suseum.

JunE, 1910. 

SDemoirs of tbe ADuscum of Comparative Zoölogy A'T HARVARI) COLLEGE.

VOL. XI. No. 1.

\section{SOLENODON PARADOXUS.}

BY

GLOVER M. ALLEN.

With Nine Plates.

CAMBRIDGE, U. S. A.:

printed for tbe Museum.

JUNe, 1910. 



\section{CON'TEN'TS.}

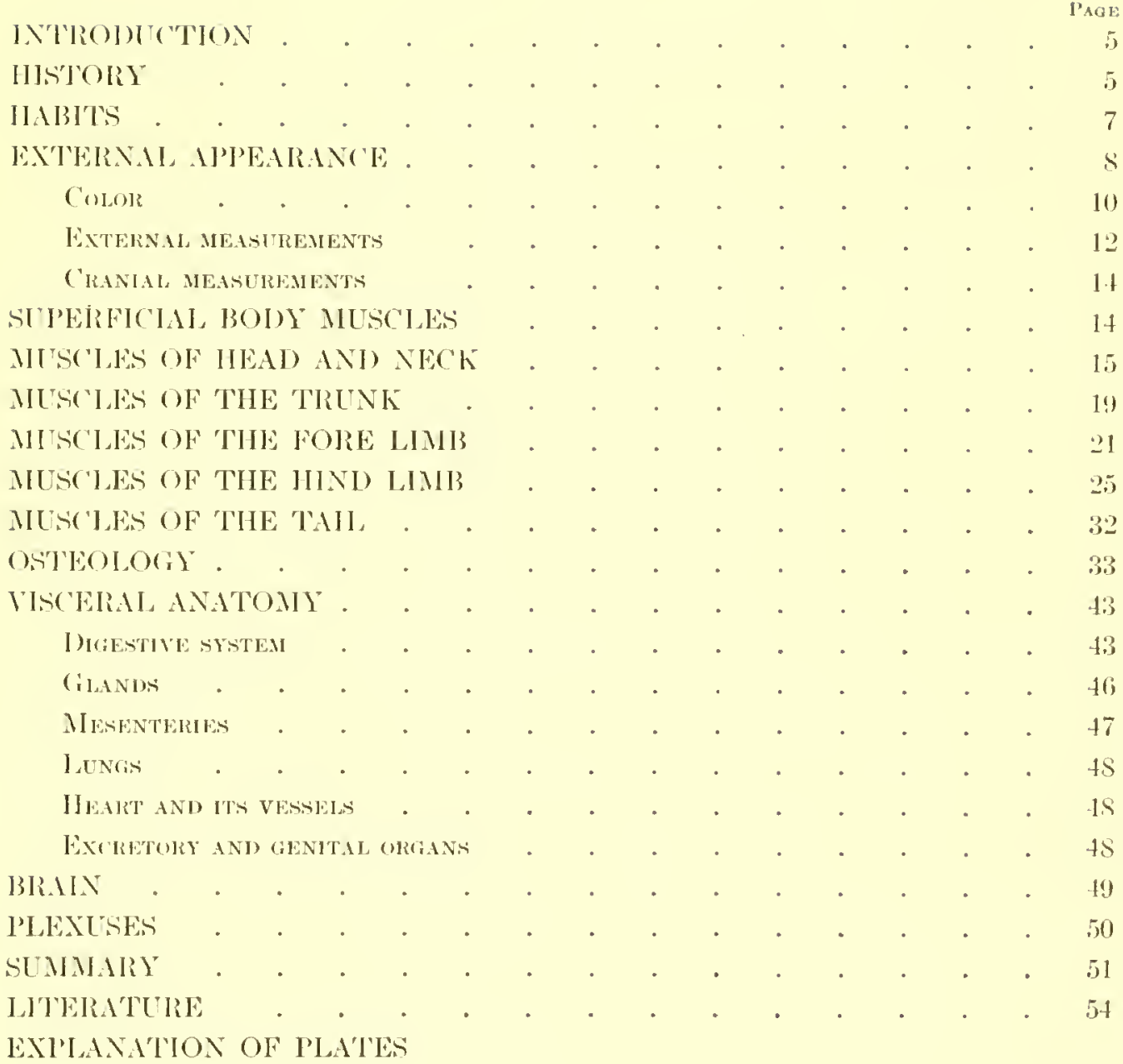





\section{SOLENODON PARADOXUS.}

\section{INTRODUCTION.}

The Museun has reecntly been fortunate in securing from Sim Domingo, a series of specimens of the rare Solenodon paradoxus Brandt. Four of these were brought alire, and were successfully photographed by Mr. Cieorge Nelson. The more interesting of the photographs were reproduced with the Annual Report of the Curator for 1907 oS. The present paper is a companative account of the general anatomy of the species, made pussible by this fresh material. For the loan of its specimens of Solenodon cubanus thinks are due the United States National Muscunn.

\section{IIISTORY.}

The brief history of this species is now well known. It was originally deseribed in 1833 by J. F. Brandt from a skin and an imperfect skull, in the St. Petersburg Academy, from Haiti. This specinen was subsecuently sturlied by Peters in connection with the Cuhan species, described by him in $186 t$. Leche states that he too, made use of this skull and other fragments of the skeleton, when in 1907 he published his extensive paper on the teeth of the Insectivora. The exact nature of the other fragments is not stated but from the text it appears that a pelvis with the sacral vertebrae labeded as of this species, was anong the material studied. These bones were figured by Leche who called attention to the remarkable characters shown hy them in comparison with those of other Insectivora. There can be no doubt, as will be shown later, that the pelvic and sacral bones figured are not those of Solenodon. Through the labors of Peters and Dobson, the anatomy of Solenodon cubanus was fairly well known more than twenty years ago, but no adelitional specimens of $S$. 
paradoxus were diseovered until 1907, when A. Hyatt Verrill secured an adult male, an adult fomale, and a young individual still rotaining its milk dentition. Of these specimens, Dr. J. A. Allen (:08) has given a brief areount. The skulls and dentition are well figured by him and critical comparison is marle with skulls of S. cubanus. The preservation of the skin and soft parts of the specimens was too poor to admit of further detailed study, however. $\Lambda$ brief paper by Verrill (:07) recounts the few facts he was able to gleam as to the habits of these animals in san Domingo. The present alecount will, it is hoped, serve partially to fill the hiatus existing in our knowledge of the general anatomy of the species.

Specimens of the Cuban Sotrnodon, were make known by Poey in 18:3t, through a communication to a Havana paper, "El planted." Later, in 1851, he gave a more detailed notice of the animal, with a colored plate, in his " $1 \mathrm{~cm}$ orias sobre la historia naturat de la ista de Cubs." Poey obtained specinens from the mountainous regions east of Bayamo, Cuba, where the animal was said to be well known. This author reviews at some length the early acenunts of the native Cuban animals, and after an exhaustive search, fails to fund any evidence that it was known to the early historians of the country. Since le was unable to attach to it any of the native names of animats mentioned by these writers, he proposed to eall it the Almiqui, a name derived from that of one of the mountains in the eastern department of Cuba near where his specimens were taken. IIe supposed the Cuban animal to be conspecific with that of Haiti and San Domingo. Gundlach subsequently obtained examples from the Sierra Maestra, but Ramon de la Sagra's statement that it occurs in the region of Trinidad, Cuba, Poey takes pains to show, is based solety on the latter's note in "El plantel" conceming vague reports of an animat in that region whose identity could not be certainly established.

Aecording to A. H. Verrill (:07, p. 56), the natives of San Domingo have various names for Solenodon paradoxus, as Orso (bear), Hormigero (ant-eater), Juron (ferret) "also applied to the mongoose," and Milqui. In his list of the mammats of Middle America and the West lndies Elliot gives it a vernacular name "Agouta," whose origin I have been unable to diseover. 


\section{HABITS.}

Of the habits of this species in a wild state very little is definitely known. According to Verrill's (:07) aceount it is "nocturnal, and spends the day in caves, holes in the coral limestone rocks and in hollow trees and logs." At night it leaves its retreat and comes forth to feed, "rooting in the earth and cultivated grounds, tearing lotten logs and trees to pieces with its powerful front claws, and feeding on ants, grubs, insects, regetables, reptiles, and fruit, and at times proving destrurtive to poultry. On several oceasions it has been known to (nter the houses in search of roaches and other vermin, and has been captured in rat-traps." Mr. Verrill's wash drawing shows the animal with tail bent around at the side of the body, and the mounted specimen in the American Musem of Natural History is prepared in a similar mamer. Such a posture for the tail is, however, probably never assumed, as its stiffness admits of but slight lateral flexure, and the muscle masses actuating its movements are almost wholly dorsal and rentral. In the living animals the tail is held straight out bohind, somewhat depressed, but slightly elevated at the tip to permit it to clear the ground. The tip alone seems capable of slight lateral movement. The tail serves very effectively as a support when the animal is cating. It then throws itself back, with the soles of the hind feet resting their full length on the ground, and the powerful tail acting as a third leg of a tripod. In this position one or botl of the fore feet can be lifted from the ground.

In feeding, the animals walk clumsily about with a stiff waddling gait, sniffing here and there at the objects that come in their path. The toes only are in contact with the ground as they walk, while the metatarsals are quite clear. They ent greedily of chopped meat, and will take lettuce as well by way of variety. Meat they give considerable mastication, opening the jaws widely as they chew. That they are capable of very quick movements, in spite of their apparent clumsiness, is seen when two or three are cating together and disagree as to the possession of some morsel of food. If one attempts to rob another, like a flash the possessor of the dainty throws its body around away from the pursuer and continues chewing greedily. Often one will seize its companion by the snout, and if wickedly inclined ean bite severely. Usually, however, they seem peaceful enough. Rarely a shrill cry is uttered, as Mr. George Nelson tells me, who has heard it while tending the captive specimens. At other times, they constantly give an explosive sniff as if clearing the nose. They are mainly active at night or in the late afternoon, and seem to dig over 
and under every movable article in the cage. They have a pronounced odor, not disagreeable, and reminding one slightly of that of a goat or a porcupine, yet characteristically different.

Verrill states that a female in his possession gave birth to three young, which, however, she promptly devoured. One of the females in the lot belonging to the Museum likewise brought forth her young in captivity, but in this case but a single one was found. If others were horn, they too must have been devoured. This young one when probably a day or so old hat the eyes and ears still closed. The hair was beginning to appear, although not sufficiently to clothe the body. It was a female (Plate 1, fig. 1) and had the single pair of mammae well developed. It lived but three days, at the end of which time the first upper and the two first lower ineisors were erupted, but the eyes and the cars were as yet unopened.

\section{ENTERNAI, APPEARANCE.}

In general form solenodon is shrew-like, with a long tapering snout, elongate head and a stout tail. The feet and limbs are not notably modified, though the fore claws are greatly developed. The great development of the snout beyond the nasal bones is a striking peculiarity, shared, however, to some extent by the African genera Macroseelides and Rhynchocyon. This proboscis in Solenodon paradoxus is cartilaginous, and consists of a long tube, quadrangular in section (Plate 5, fig. 2) and deeper than wide. The nasal septum divides the eavity of the proboscis and is continued into the nasal chamber; a projecting ridge on each side of the septum, partly divides the lunen of the proboscis into a dorsal and a rentral tube. At its proximal end the prohoscis is rentrally supported by a small round bone, the os proboscidis, and laterally it is held in place by a short triangular cartilage on each side from the upper free edges of the premaxillaries. These cartilages are loosely bound to the sides of the proboscis by comnective tissue. The tip of the snout has a naked rhinarim about a centimeter in length ventrally whose posterior border is ill defined dorsally just posterior to the nostrik, but below it is sharply marked off from the surrounding haired surfaces by a slight groove. A median groove runs from the upper incisors to the tip of the snout which here is slightly emarginate. The nostrils open laterally and are somewhat erescentiform. The sides of the snout are supplied with about a dozen large vibrissae, the longest of which measure about $65 \mathrm{~mm}$. There are in addition shorter hairs from swollen bases, that are coarser 
than those surrounding and are cloubtless tactile. A single vibrissa 25 $11 m$. long is present on the midline of the chin below the angle of the mouth. Two or three long coarse hairs are also found midway between the eye and the ear.

The ear is large, and nearly round in general outline, though the anterior margin is straight. A large posterior basal lobe is marked off by a conspicunus notch halfway on the posterior border. A smaller lobe is similary indicated at the base of this larger lobe. The whole appears to be comparable with the antitragus of other mammals. On its internal surface is a rounded ridene. This and the more ectal portion of the antitragus are thinly covered by hair. 'The tragus, at the base of the antero-internal border of the ear, is a barely indieated marginal prominence. A prominent netatragus is well dereloped, just below and anterior to the center of the ear. It consists of a large rounderl lobe anteriorly with a short small ridge-like projection just posterior and parallel to it. These two prominences are placed slightly obliquely to the vertical axis, indined forward. From the notch separating postero-dorsally the antitragal lobe, a prominent ridge is developed, with a somewhat crescentiform outline, the concavity rontral, plojecting inwal nearly a thirel the diancter of the ear. There is on each ear, directly above this ridge and about :3 mun. from the posterior rim of the conch, a low round papilla. The border of the ear is slightly enuarginate above this papilla, a result possibly of injury, since the two notehes are not of exactly the sane appearance in the two ears. The distal lalf of both inner and outel surfaces of the conch is sprinkled with minute appressed hairs. The ear of st. cubanus is slightly larger.

The body is round and stout, the linds heary and muscular. The latter present no renarkable modifications, but the claws of the anterior digits are greatly developed, apparently lor scratehing the surfare luther than for burrowing in the earth. In the Cuban Solenodon they are alsolutely longer and more slender, although the animal itsolf is smaller. The three middle digits of fore and hind foet are subequal. The innermost digit is in cald case the shortest. The hind foot is of a very gencralized type, and with long metatarsal bones suited to the semi-plantigrade method of walking.

The tail is long and stout in S. paradoxus, though rather more slender, relatively, than in S. cubamus. In hoth it is covered at the base by clense hairs, fine and very short, which extend forwird to the posterior part of the rump, where the long lairs abruptly stop. The tail is covered with rery small scales, between which are seattered minute hairs. Near the base of the tail there are ahout 36 seales in a single transverse row. 
The mammae are two in number in both species, inguinal, or even postinguinal, situated far apart, on a line just anterior to the genital opening. The number and position of the mammac are thus remarkably different from those in Centetes with its twelve pairs extending from the axillae to the groms. Potamogale, however, has but a single inguinal pair.

The general body hair is long and coarse dorsally, becoming finer and slightly crinkled on the sides and venter. On the back two sorts of hairs are distinguishable: (1) the abundant shorter and finer hairs, and scattered among these, (2) single coarse hairs. The latter appear to have larger follicles and these, in a skin of S. cubanus that has lost some of the bair, are seen to be arranged in oblique rows, at intervals in the dried skin of about $5 \mathrm{~mm}$. In a young Solenodon paradonus three days old (Plate 1, fig. 1), these coarse hatirs are well developed, averaging some $5 \mathrm{~mm}$. in length, and seattered at close intervals in similar oblique rows. With a hand lens the more abundant fincr lairs may be seen at the bases of these larger ones. They are very minute and seem to he at least three between each two of the large bristles in a transverse row, while others are scattered between the rows. It seems not unlikely that the coarse spiny hairs present mainly in a longitudinal row on each side in the young of Contetes are homologous with these bristles in Solenolon. The further cehinate development of the corresponding hairs in Centetes is seen in the adult that has seattered spine-like hairs over the dorsal area mingled with the more abundant finer hairs of the general body surface. The further development of a spiny dorsal covering such as is present in Erinaceus, would seem to be thus foreshadowed in these two genera. The statement of Verrill (:07) that the legs, snout, and tail are naked, and that the rump is bare, is not strictly correct. The rhinarium is quite hairless, as are also the soles of the feet, but the rest of the snout, legs, and rump are covered with minute hair, and small appressed hairs spring from between the seales of the tail.

Color.- In the series of skins at land there is great variation in the extent and intensity of the colors, and this appears to be independent of sex. The commonest type (Plate 3 ) has the dorsal surface of the head from the base of the snout to the ears and nape, black. The basal half of the hairs is pale buff. Ahout the eye the long hairs are reflexed in a sort of rosette, and their pale bases thus form an eneircling light-colored area. The black-tipped hairs extend over the mid-dorsal area of the back to the rump and are everywhere intermingled with pale, nearly buff-colored hairs, that give thus a grizzled effect to the dorsum. Ventro-laterally from the median line, the black hairs decrease in number, while 
the buff hairs become more numerous, so that on the sides of the body and on the forearm they produce a clear buff or eream buff. This color of the sides extends ventrally from the abdominal region to the upuer part of the chest where it passes into a deep ferruginous, almost chestuut, over the ventral surface of the throat, upper chest, bases of the fore limbs and dorsally to the sides of the neck. The inguinal region also is ferruginous. The short hairs of the feet and distal portion of the snout are of the same buffy color as the venter, with a slight admixture of ferruginous hairs around the mouth. A whitish nuchal spot, about 15 by $10 \mathrm{~mm}$. in extent, is present in all but one of the specimens, and secms to be a characteristic of the species. The presence of a white nuchal spot is due to the faliture to meet of the two lateral pigment areas whose centers are on the sides of the neek, as has been elsewhere indicated by the writer. The condition of partial albinism thus produced has here become fairly permanent, so as to result in a definite pattern. A similar restriction of the demal pigment of the tail his taken place, so that a varying length, usually nearly the clistal half, is white.

Variations from the type of coloration above described oceur through an increase or a decrease in the intensity of the pigment. One fomale shows a maximum of increase in the black of the dorsum. This color is deep on the head and extends to the ellows on cach side, while on the back the admixture of buffy hairs is very slight until well cown on the sides of the body the clear buff area is reached. The white uuchal spot exists in this specimcn as a few scattered hairs, hardly noticable. Ientrally the lower surface of the forearm and the inguinal region from tibia to tibia is suffused with ferruginous.

The opposite extreme is shown by another female in which the black is so dilute, not only on the dorsal area as a whole, but in the separate hiirs, that it appears as a distinct brownish, nearly drab of Ridgway's Tomenclature of colors, grizzled with buff hairs. The latter become slightly tinged with rufous on the sides and venter.

The ferruginous tint (Plate 2) is exceptionally well developed in two large and apparently old females and in a third smaller animal, an adult male. In the brighter of the two old females the buffy hairs of the back and sides of the head and body and on all but the nid-ventral region are replaced by ferruginous, even the nuchal spot being of this tint. The ventral portion of the chest and the lower throat where the ferruginous is brightest in other specimens, have in this example berome so intensified that they are nearly black. The third bright specimen above mentioned is the most brilliant. The dark throat area is nearly 
maroon shading into deep forruginous on the sides of the neek, while posteriorly the sides of the body and the venter are orange-rufous, somewhat more ferruginous on the lower surface of the arms and on the inguinal region. The nuchal spot in this specimen is bright buff.

A very young female (Plate 1 , fig. 2) is much paler in color than any of the adults. The dorsal area has a general tone of broeolli brown due in part to the dilute pigmentation of the black hairs and the paleness of the buffy hairs, which are here of a light cream buff. This color also extends over the sides and midventral region becoming more intense a buff on the inguinal region and on the lower throat and chest. The ferruginous tints of the ardult are quite alsent at this early age.

The long vibrissae are usually buffy or ferruginous, but sometimes black.

Between the various styles of coloration just described all grarlations oceur. The black of the dersun may be so restrieted as to cover but a narrow median area or it may extend ahmest to the ventral border of the body. Again it may be so intermixed with buffy hairs that instead of showing deatr black it appears as a miformly grizzled drab, with all intermediate gradations of coloring. The color of the underparts in the youngest specimens varies from a uniform buff to ochracrous-buff and ocharaceous, but in the adults the buff is often confined to the sides and abdomen and shates into ochrareous on the inguinal region and into ferruginous on the chest and throat. Others, however, bave the inguinal area buff like the sides and abdomen. Again, the ferruginots of the throat may extend ventrally upon the abdomen, reaching an extreme in the rase of an old female that has the entire belly and siles suffused with this color. Some have the abdominal surface nearly elear drab. Nll the specimens show the white Intalal patch cxcept one or two highly colored adults in which this area is suffused with the buff or the ferruginous of the sides and belly. The white spot varies from a narrow streak $6 \mathrm{~mm}$. wide and $12 \mathrm{~mm}$. long to a blotele about 20 by $25 \mathrm{~mm}$.

The great difference in wolor hotween s. puradoxus and S. cubamus has heen pointed out by Dr. J. A. Nhen. In the Cuban species the pelage is fincr and longer. The torsum is more uniformly dark without the admixture of lighter hairs. The uniform dark color of the back continues on to the feet, the thighs, for'arms and (hest while the greater part of the head and part of the mid-rentral area are pale yellowish, or in alcoholie specimens nearly white.

Extemul measurements.-The following measurements are of ten adults, a young male, and a second younger animal, a female, but three days okd, born in 
captivity. All but the last were alcoholic specimens. The last was measured shortly after its deatl. Measurements are in millinisters.

\begin{tabular}{|c|c|c|c|c|c|c|c|c|c|c|c|c|c|}
\hline 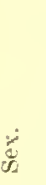 & 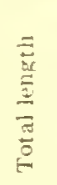 & 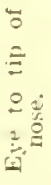 & 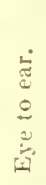 & 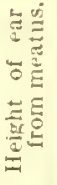 & 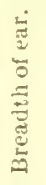 & 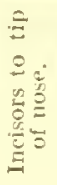 & 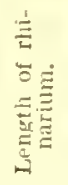 & 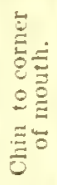 & 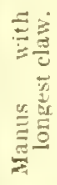 & 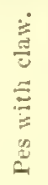 & 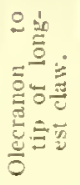 & 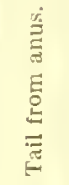 & 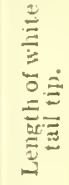 \\
\hline 0 & 520 & 67 & 34 & 29 & 24 & 31 & 9.5 & $2 \pi$ & 52 & 6s & 106 & 222 & 71 \\
\hline $0^{\circ}$ & 501 & 71 & 31 & 31 & 26 & 35 & 10.5 & 32 & 57 & 70 & 111 & 251 & 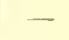 \\
\hline $0^{\circ}$ & 525 & 6.1 & 27 & 30 & 22 & 35 & 11.0 & 33 & 59 & 69 & $10 s$ & 211 & 130 \\
\hline $0^{\circ}$ & 526 & 69 & 3.5 & 29 & 24 & $8 s$ & 11.5 & 39 & 55 & fis & 110 & 240 & 128 \\
\hline 8 & 530 & 69 & 35 & 31 & 25 & 39 & 10.0 & 30 & 53 & 67 & 111) & 222 & 141 \\
\hline$\sigma^{1}$ & 36.5 & 58 & 2.1 & 26 & 22 & 32 & 11.0 & 25 & 419 & (6) 1 & SS & 154 & 77 \\
\hline q & 551 & 71 & 32 & 27 & 2 & 39 & 11.0 & 2!) & 51 & 67 & 101 & 238 & so \\
\hline 오 & 528 & 6.5 & 30 & 25 & 22 & 35 & 9.0 & 20 & 11 & tis & 104 & -12 & 121 \\
\hline ? & 531 & 68 & 32 & 29 & 25 & 3.5 & 10.0 & 30 & 51 & 70 & 109 & $23 s$ & 94 \\
\hline ? & 545 & 72 & $: 36$ & $2 ! 9$ & 24 & 40 & 10.0 & 35 & 51 & (i.S & $10 \bar{T}$ & 240 & 135 \\
\hline 9 & 543 & 69 & 29 & $2 ! 9$ & 23 & 37 & 11.0 & 29 & 53 & bis & 108 & 240 & 99 \\
\hline$q^{2}$ & 19.5 & 333 & 15 & 9.3 & $s$ & 18 & 5.5 & 11 & 25 & $3: 3$ & 47 & 7..5 & - \\
\hline
\end{tabular}

This table shows that adults of both sexes are csentially alike in size, and present a comparatively small amount of rariation in the measurements. Is additional data for comparison the following measurements of two males and two females are given following the order in Dr. J. A. Allen's (:08, p. 512) paper:

Length of head (in straight line) Breadth of head in front of ears Length of eyeliels (fissure)

Distance of eyes from each other

Brearlth of proboscis at hase

Height of proboscis at midule

Height of proboseis at base

Distance between corners of mouth

Thickness of tail at midile

Length of hand to end of 3 d digit (without claws) . . . . . . . .

" "1st digit (without claw)

" " claw of 1st digit (over curviture) "

" " 2 l digit (withont claw)

" " claw of $2 \mathrm{~d}$ digit (over curvature)

" " 3 d digit (without claw) . .

" " claw of 3i ligit (over curvature)

" " "4th digit (without clinw)

" " claw of 4th digit (over curvature)

" "5th digit (without claw).

" " claw of 5 th digit (over curvature)

Jength of foot to end of midelle digit (without claw)

" " 1 st digit (without claw")

" " claw of 1st digit (over curvature)

" "2d digit (without claw)

\begin{tabular}{|c|c|c|c}
0 & 5 & 9 & 9 \\
120 & 127 & 119 & 127 \\
44 & 51 & 44 & 52 \\
5 & 5 & 5.5 & 4 \\
28 & 30 & 27 & 33 \\
15 & 17 & 20 & 17.5 \\
11 & 11 & 10 & 9 \\
18 & 16 & 17 & 16 \\
30 & 26 & 26 & 35 \\
10 & 10 & 10 & 11 \\
34 & 41 & 37 & 42 \\
9.5 & 9.5 & 10.5 & 9.5 \\
8 & 11 & 10 & 10 \\
11 & 15 & 11.5 & 16 \\
15 & 21 & 19 & 17 \\
17 & 16 & 17 & 16 \\
18 & 21 & 19 & 17 \\
16 & 17 & 14 & 17 \\
17.5 & 20 & 18 & 17 \\
12 & 12 & 11 & 14 \\
11 & 11.5 & 10.5 & 11 \\
59 & 59 & 60 & 64 \\
10 & 9.5 & 9 & 9 \\
7 & 8 & 7 & 8 \\
13 & 14.5 & 14 & 16.5
\end{tabular}

${ }^{1}$ Immature.

${ }^{2}$ Three day's old. 


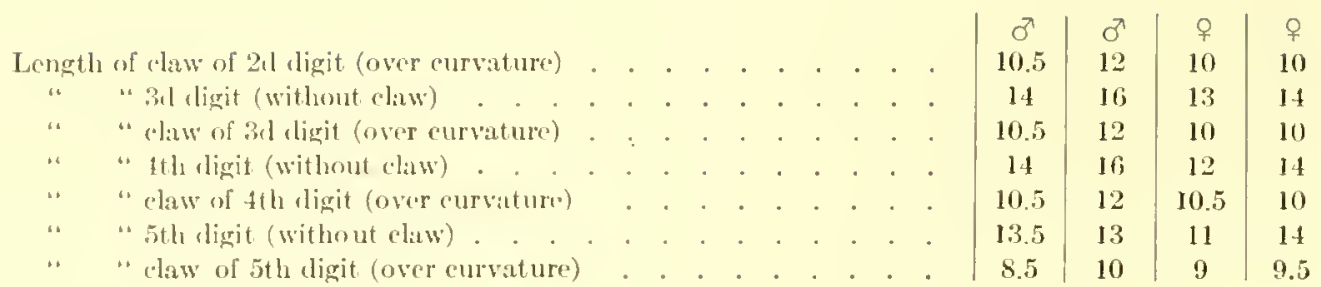

Cranial measurements. - An adult skull exhibits the following mensurements: greatest length, 87; greatest median length, 82.8 ; basal length, 77 ; palatal longth, 37; interorbital constriction, 15.8; breadth outside first incisors, 10.5; hrealth outside seend premolars, 17; greatest width between outcr molar margins, 24; greatest prezygomatic brealth, 34.7; greatest postzygomatic brealtlı, 34; mastoid breadth, 27; occipital breadth, 19.7; maxillary tonthrow (including incisors), 40; length of mundible, 5s; greatest height at coronnid process, 26; length of mandibular toothrow, 35.5; width of condyle, 9 ; length of mandibular symphysis, 19.

\section{SUPERFICIAL BODY MUSCLES.}

The stemo-facinlis is a thin sheet of muscular fibers arising from fasciae along the anterior part of the pectoralis. The fibers from opposite sides are somewhat interlaced on the throat. This sheet extends forward over the prominent thyroid glunds to the mandibular symphysis and dorsally on to the sides of the face, beconing inserted by thin tendinous fibers into the skin of this region.

The panniculus camosus is extraordinarily developed and thiekened orer the dorsal region, where it forms a tough, mainly tendinous sheet about $2 \mathrm{~mm}$. thick. This sheet is attarhed to the tips of the dorsal spines by thin strands of muscle and tendon and to the vertebral edge of each scapula and the posterior third of the seapular crest. A few slight strands of tissue connect it with the ecto- and cnto-pectorales ventrally, and its main insertion, after dipping beneath the ectopectoralis, is upon the antro-internal sicle of the humerus about a centimeter distal to the head. This insertion is tendinous and some $6 \mathrm{~mm}$. long. Anterodorsally this great investing sheet is more or less continuous with the thin muscular and tendinous sheet of trapezius museles that covers the top of the head and neck and inserts along the anterior length of the scapular spine. Posteriorly the panniculus merges into a thin sheet investing the thigh as far as the knee and backward around the base of the tail. It is everywhere closely connected to the skin. 
A flat strand of muscle from 2 to $5 \mathrm{~mm}$. wide (Plate 4, fig. 1,e) arises from above the articulation of the 14 th rib on each side and passes forwarl for about $60 \mathrm{~mm}$. to become inserted into this great tendinous sheet some $30 \mathrm{~mm}$. posterior to the axilla. This appears to be the dorso-cuticularis, and is apparently narrower than in Gymmura or Potamogale.

\section{MUSCLES OF IHEAD AND NECK.}

Compared with Centetes, Gymnura, or Potamogale, the anterior museles of the snout seem to show less eomplexity in folcnodon, but resenble more nearly those of Myogale as figured by Dobson, whose speeimen of Solenodon cubanus was in too poor a state of preservation to permit of exatet detemination of these muscles.

The platysma myoides is a flat superficial musele, well developed and firmly attached to the skin from the lambdoid erest forward along the sides of the face and lower jaw.

The zygomaticus major (Plate $\mathbf{5}$, fig. $\mathbf{1 , b}$ ) is a relatively small muscle arising from the bony ledge of the antorbital pit just above the last premolar. It passes into a small round tendon at about the level of the anterior incisors, and ruming ,iust to one side of the midventral line, inserts on the ventral portion of the tip of the eartilaginous proboseis. Its action is to depress the snout, but it evidently is of limited use, as the vertical play of the proboscis is not very great.

The levator labii supcrioris proprius (Plate 5, fig. 1, c) is a large nuscle attached along the entire anterior edge of the orbit from the ventral border of the eye nearly to the dorsal line. It passes forward as musele to the tips of the nasals where it becomes a flat tendon and runs to the tip of the proboscis below the median line.

The levator labii superioris et erector vibrissarum (Plate 5, fig. 1, a) originates anteriorly to the orbit, between the two muscles just deseriberl and ectal to the opening for the facial nerve. It is likewise more or less firmly attached to the antero-lateral face of the maxillary where it breaks into numerous small threadlike tendons that pass to the bases of the vibrissae with which the snout is well supplied. These fibers are firmly united by investing tissure and museular strands to the side of the cartilaginous proboscis, to which they are undoubtedly able to impart a slight lateral motion. Ventrally this muscle is elosely conneeted by tendinous tissue to the orbicularis oris. It is richly supplied with nerves. 
Temporalis (Plate 5, fig. 1,e) is large, and arises along the median and parictal crests. Its lam mass on the dorso-lateral surface of the skull is about $40 \mathrm{~mm}$. long and $20 \mathrm{~mm}$. broad. It passes ventro-laterally to a tendinous insertion at the tip of the coronoid process of the jaw and on its ental aspect.

$A$ smiall muscle (Plate 5 , fig. $1, d$ ) arises from the lateral surface of the posterior zygomatic root and passes dorsal to the masseter as a narrow band some 5 mm. wide, to its insertion along the exterior base of the coronoid process for a distance of about $8 \mathrm{smm}$. This seems to correspond to what Dolsson eonsirlers in Gymnura a second heat of the temporalis. In Solenodon, however, it is quite separate from the temporalis throughout.

Another muscle, corresponding to Dobson's third head of the temporalis in Gymnura, arises much as in that form from the imer clorsal margin of the postrior zygoma, and curving flownwh and forwarl, is broadly inserted as a flat muste in the hollow of the exterior face of the coronoid process.

The musseter originates along the posterior portion of the malar part of the zyogra for a distance of $7 \mathrm{nmm}$, and is inserted along the posteru-ventral surface of the ramus.

The digastric muscles (Plate $\mathbf{5}$, fig. $1, f$ ) are rather small, arising along the inferior side of the lambdoid erests about a centineter from the vertex of the skull. Each as it passes forward, tapers to a tendinous insertion at the tip of a small bony process on the inner ventral margin of the manclible about 13 mm. anterior to the angle of the jaw.

Pterygoideus internus is a short thickish sheet of muscle arising extemally to the pterygoid on each side and inserting at the angle of the ramus.

Pterygoideus extermus is smaller, and arises just externally to the last from the sphenoid region. It inserts on the lower jaw inside the neck of the mandibular condyle forward to the inferior dental foramen.

The mylo-hyoid arises as a thin sheet from the imner ventral margin of each ramus. There is a faily well defined median raphe where the two clements, one from each side, are united. The fibers stretch across between the two rami, and posteriorly to the insertion at the antero-ventral margin of the basi-hyal. A deeper and a more superficial layer is with sone difficulty to be distinguished in this musele.

The stylo-hyoid is well developed and conspieuous. It is a narrow band arising from the ventral side of the mastoid proeess, and passing superficially to the digastric, is inserted on the side of the thyroid bone of the larynx. This muscle scems not to have been previously found in Solenodon. It is said 
by Dobson to be "very feeble" in Centetes; but in Potamogale is well developed. Dobson's figure of the latter (Dobson, '82-'90, pl. 9, st. h.) shows this muscle in nearly the same proportions as in solenodon.

The sterno-hyoid is the most ventral of the museles of the throat. It arises from the inner or dorsal side of the second segment (mainly) of the sternum. This muscle is divisible into two elements, which, however, are so elosely united in the mirl-ventral line that the separation is not clearly defined until the investing tissue is removed. The stemo-hyoid is broadly inserted into the rentral surface of the thyrohyal cartilage.

The sterno-thyroid of each side is smaller than the corresponding stemohyoid, and arises just lateral to it. It passes forward along the side of the trachea to the thyroid cartilage, on to the side of which it is inserted by two short muscular branches.

The crico-thyroid is represented by short muscles on each side, that pass obliquely from the crieoid to the thyroid eartilage.

Beneath the mylo-hyoid on each side, from the symphysis for about 8 mm. posteriorly, arise the genio-hyoids. They are closely approxinuted medially and fill the space between the rami. They are inserted on the ventral side of the basi-thyrohyal.

The genio-hyoglossus is as usual, a thin flat sheet of muscle, arising from the basihyals and radiating out anteriorly to the tongue.

The trapezius muscles (Plate 4, fig. 1, $a, c, d$ ) arise along the mid-dorsal line from the vertelural spines to the occipital crest at the posterior edge of the skull, forming a broal thin sheet. They insert along the spine of the scapula beginning at about $15 \mathrm{mmm}$. from its vertebral elge, forwar for some $28 \mathrm{~mm}$. A slight break indicates the division between the spino- and acromio-trapezius, but the latter and the clavo-trapezius are not clearly separable.

The supracervico-cutaneus (Plate 4, fig. 1, b) arises from the mid-dorsal line of the posterior half of the neck and passes ventrally to become confluent with the broad tendinous sheet attached to the skin along the front edge of the fore slioulder.

The rhomboideus arises underneath the trapezius, by two heads. The first consists of a single long band from the mid-dorsal portion of the neek from oceiput to about halfway on its length. The second is a longer sheet from the last cervicals and first four or five dorsal spines. The muscle is inserted along the posterior inner border of the scapula from just below the angle along the entire vertebral margin. A sinnilar partial division of this muscle was noted by Dobson 
for Solenodon cubamus, and the homology of these two portions with the rhomboideus anticus and posticus respectively of Gymmura and Centetes is suggested. In Potamogale Dobson found these muscles coaleseed to form a single sheet.

The occipito-scapularis (Plate 5, fig. 4, b) arises along the lambdoid crest for about $10 \mathrm{~mm}$. lateral to the mid-dorsal line. It passes back to the posteroexternal face of the scapula about $6 \mathrm{~mm}$. below the coraco-vertebral angle where it is broadly inserted along the vertebral exge of the scapula. Its length is about $80 \mathrm{~mm}$.

The sterno-mastoideus (Plate 5 , fig. $4, g$ ) takes origin from the ventral surface of the presternum, where it is slightly overlapped by the ectopectoralis. It passes forward as a museular band to a tendinous insertion at the lateral extremity of the lambdoid crest just above the ear. This tendon, as in Centetes and Gymmura is united with the tendon of the cleido-mastoideus as a eommon insertion. The cleido-mastoideus (Plate 4, fig. 4, $h$ ) takes origin from the anteroexternal edge of the ventral half of the elavicle.

The levator cluviculue (Plate 5, fig. 4, a) is well developed and takes origin from the atlas only near the median line at the antero-ventral margin. It passes back as a narrow band to a tendinous insertion on the ectal edge of the metacromion just back from its tip.

The splenius arises along the dorsal line from about as far back as the fifth dorsal vertebra. Passing forward, it inserts along the mesial portion of the lambdoid crest from the vertex to just ental of the stemo-mastoid insertion. Anteriorly the portion arising from the first of the cervicals may be more or less readily separated from the postcrior part of the muscular sheet.

The complexus arises from the transverse processes of the vertebrae from the fifth cervical to the sixth dorsal. It has the usual insertion under the splenims. A lateral and a more median portion may be distinguished.

The rectus capitis posticus major arises from just below the top of the neural spine of the axis and passes forward to its insertion beneath the lambdoid crest, in close union with the rectus capitis posticus minor whose origin is slightly more lateral.

The oblique capitis supcrior originates from the tip of the transverse process of the atlas, and goes forward to its insertion below the lambdoid crest at a point about $7 \mathrm{~mm}$. lateral to the vertex of the occiput. It is also united by a slight raphe to the ectu-proximal portion of the digastric muscle.

The oblimens capitis inferior is large and arises from the postero-lateral portion of the spine of the axis. Its course is obliquely forward to the posterior side of the transverse process of the atlas. 
The lerator anguli seapulae takes origin from the transverse processes of the three last cervical vertebrae and is inserted along the subscapular surface of the scapula, internal to the rhomboicteus, from the coraco-vertebral angle to the insertion of the scrratus magnus. In Centetes as in Ciymnura and Potamogale this muscle is united with serratus magnus. In Myogale, however, the conclition is practically the same as here described for Solenodon, though in the forner the levator is slightly more cleveloped.

\section{MUSCLES OF THE TRUNK.}

The latissimus dorsi (Plate 4, fig. 1, $f$ ) is a large superficial muscle, consisting of a thin sheet of fibers covering the dorsal half of the thorax from the last rib forward to about the ninth rib. It arises from the spines of these vertebrac as well. Antero-laterally it becomes a narrow tendon which inserts on the antero-internal face of the humerus near its head, ental to the insertion of the teres and just above it. At the antero-ventral edge, just before the muscle passes into the tendon it is connected by a raphe with the epitrochlearis and by a few strong fibers to the ventral edge of the teres. This peculiarity was noted by Dobson in the Cuban Solenodon. Along the ventral edge of the latissimus where it covers the thorax, a branch from each of the dorsal nerves takes exit.

The serratus magnus has the usual general origin from the anterior portion of the thorax. Its posterior extension reaches the ninth rib. The muscle is inserted along the posterior inner edge of the seapula at the gleno-vertebral angle.

The oblique muscles present no especial peculiarities. The cetobliquus arises from the pubic symphysis on either side and passes upward and forward on to about the lower hall of the ribs to the ventral border of serratus magnus, and the front of the ilium. The entobliques has a strong tendinous origin from the anterior end of the ilium and along the pubis to the midventral line. It passes as a thin sheet antero-ventrally to the median line and vent ral border of the ribs.

The rectus abdominis originates as a partly tendinous thin sheet from the rentral third of the first rib. It passes back to unite just behind the xiphisternum with its fellow of the opposite side, and the two are inserted by muscular fibers on the anterior rim of the pubis for a distance of about $S \mathrm{~mm}$. cach side of the symphysis.

As in Gymnura, Centetes, and Potamogale there is a clavieular portion to the cetopectoralis. The sternal portion of this muscle takes origin along the entive median length of the stcrnum from the tip of the manubrimn to the base 
of the expandad cartilaginous end of the xiphisternum. The fibers converge as they pass obliquely forwarl to the insertion, $16 \mathrm{~mm}$. in length, along the anteromedian edge of the middle third of the humerus. The clavieular portion of this muscle (Plate 5, fig. 4, c) originates from the ceto-posterior border of the clavicle and is more or less confluent distally with the main mass of the cetopectoralis, though practically distinct to the common insertion.

The entopectoralis (Plate 5, fig. 4, f) arises just underneath the ectopeetoralis, from the antero-rentral margin of the second rib, posteriorly to the base of the last sternal rib as a thin flat sheet, that becomes thicker as its fibers converge anteriorly to a tendinous insertion $4 \mathrm{~mm}$. long at the head of the humerus, on its median face, just ental to the bicipital groove. At about the insertion of the fifth rib, there is a slight division of this muscular sheet so that its origin may be said to consist of an anterior and a posterior portion. These two parts evidently eorrespond to the two divisions described in Centetes by Dobson, although in that genus they are somewhat more extensive and distinct.

The subclavius (Plate 5, fig. $4, d$ ) is a very narrow band of muscle arising from a tendon on the anterior side of the first rib, at about $2 \mathrm{~mm}$. (lorsal to the stemum. It passes antero-dorsally to a tendinous insertion on the ental aspect of the clavicle just proximal to its articulation with the acromion. This muscle is about $30 \mathrm{~mm}$. long and $2 \mathrm{~mm}$. or less in width. In Centetes, arcording to Dobson, it is not present, hut in Gymmura is dereloped about as in Solenodon.

About $3 \mathrm{~mm}$. dorsal to the origin of subseapularis, is the large tendinous insertion of scalemus secundus or anticus. It arises from the transverse proecsses of all the cervical vertebrae except the athas, by tendinous and muscular fibers.

Scalemus primus arises dorsally to the last, from the transverse processes of the $3 d, 4$ th, and 5 th cervicals and is inserted on the thorax as far back as the fourth rib, in close juxtaposition to the rentral border of serratus magnus. The brachial plexus takes exit between the two seateni.

The sealenus nuscles appear thus to be much like those of Centetes and Potamogale, and differ from those of Cymmura and Erinaceus in that the anticus is present, whereas in the last two, according to Dobson, it is absent. 


\section{MUSCLES OF TIIE FORE LIMIB.}

The coracoideus (Plate 5, fig. 5, c) arises by a conspicuous tendon from the cutal face of the eoracoid process. The eaput lreve is inserted on the inner mesial surface of the humerus at a point $13 \mathrm{~mm}$. from its head; the caput longe passes as a tendinous band from 22 to $3 \mathrm{~mm}$. wide expanding somowhat distally to its insertion on the postero-internal portion of the hunerus just proximal to the epitrodilea. Dolson makes the brief statenent that this muscle in folenodon is very sinnilar to that in Erinaceus and Centetes. In Gymmura and Myogale the muscle was not detected, while in Potamogale the (a) ut longe was wanting.

The subscupuluris (Plate b, fig. $5, a$ ) is stromgly developed. It is attatehed on the subseapular surface of the sapula, and arises from there rather distinct sets of filers: (1) a sot originating along the colaco-vertebral margin of the scapula nearly to the coraco-vertebral angle; (2) fibers from the vertebral margin of the seapula near the insertions of levator anguli scapulac and serratus magnus; (3) a bundle of fibers arising along the glcuoid margin of the seapula, partly on the ental surface of the latter. Tendinous fibers from these three divisions run forward as a large tendon to an insertion on the trochin of the lumerus underneath that of the eoraroidens.

The large supraspinatus (Plate $\mathbf{5}$, fig. 6 , i) is from almost the entire supraspinous fossa exerpt its most postrior portion, from the coraco-rertelonal nuargin to the margin of the mesoscapulat, becoming tendinous as it passes under the acromion to its insertion on the trochiter.

The spino-dettoiders arises along the mesoseapula from just posterion to the metacromion. It passes forward and slightly inward, to its insertion on the crista deltoidea of the humerus. Here it is joined by the acromio-deltoideus from the infraspinous borker of the alcomion, a smillor, natrower musde.

The origin of the infraspinatus. (Ilate 5 , fig. $(i, h$ ) is underneath that of spino-deltoidens, from the whole length of the infranpinous fossil, except at the cremo-vertebral angle, where it meets and partly unites by ar rifle, with the teres. Its tendon inserts on the trochiter, adjacent to that of the supraspinatus, but slightly distal to it.

The peculiar relations of the epitrochlearis (Plate 5, fig. 5, d) have been described by Dobson in Solenodon cubemus and they are the sume in $S$. paradoxus. This muscle arises from a raphe about $18 \mathrm{~mm}$. long, from the commencement of the tendinous jortion of the latissimus dorsi. It is also connected at this point by a few fibers from the teres. The insertion is at the olecranon. 
The micostulis (Plate 5, fig. 6, a) or "teres minor" is a smatl muscle, intimatcly associated with the infraspinatus. Its origin is from the glenoid border of the scanoula, back about $11 \mathrm{~mm}$. along the glenoid margin. Its insertion is ly a very short tendon just distal to the inscrtion of the infraspinatus on the trochiter. According to Dobson, this muscle is lacking in Contetes, Gymnura, and Potamogale. It is present, however, in Erinaceus and largely developed in Myogale.

The meditriceps (Plate 5, fig. 6, b) is a large, prism-shaped muscle, from nearly the anterior third of the glenoid margin of the seapula. It tapers clistally to a short tendon inserted on the olecranon.

The eetotriceps (Plate 5 , fig. $6, e$ ) arises from a shect of tendon on the proximal part of the crista deltoidea. It is a flat muscle and gradually inereases in breadth to its insertion on the ectal face of the olecranon, anterior to that of the meditriceps, to whose tendons for the space of about a centineter it is here intimately connected.

The entotriceps (Plate 5, fig. 6) is clivisible into three fairly distinct rarts. The first of these seems comparable with the intermedia and the candalis divisions as present in the eat. In Solenolon these two divisions are not to be (lifferentiated, but arise as a single muscle from the posterior side of the humerus just distal to its head. The insertion is by tendon on the entero-dorsal side of the olecranon as far as the sigmoid noteh. A second division, probably homologous with the division ephalica of the cat, arises along the postero-external side of the distal half of the humerus and inserts on the ectal aspect of the olecranon, ental to the insertion of the ectotriceps. The third clivision is apparently the same as the division brevis, and consists of a short bundle of muscular fibers from the ectal surface of the epitrochlea to a tendinous raphe near the distal extremity of the division cephalica. The condition of the triceps muscle in Solenodon secuss to be much the same as that deseribed by Dohson for Gymnura, and one is led to infer that its relations are nearly identical in Centetes and Potamogale.

The supinator longus is absent in Solenodon, as in Gymnura, Erinacens, Centetes, Potamogale, and the Talpidae.

The bieeps arises by a single head, as a strong rounded tendon about a centimeter in length from the dorsal lip of the glenoid fossa and base of the coracoid process. Its main mass is spindle-shaped and flattencel. Distally it passes into a tendon that is inserted mainly on to the ecto-dorsal alge of the ulna, just distal to the lip of the sigmoid noteh; a slip of tendinous tissue also ennnectis 
it with the proximal end of the radius at the point where radius and uha meet at the articulation with the humerus. This is the condition likewise in Centetes, and practically that found in Cymnura, where, however, only the uhar insertion is described. In Dobson's specimen of Solcnodon cubamus he found tuv lieads to this muscle. The second he describes as "a long and very slender tendon from the coracoid process immediately above that of the coraco-brachialis." This, he states, "becomes muscular low down, and unites with the belly of the glenoid head about the eommeneement of the lower thirel of the humerus; the muscle thus formed terminates in a tendon which is mainly inserted into the radius." Possibly the cloulde origin of the bieeps in his specimen was an individual anomaly, or the condition in the Cuban species is different from that obtaining in s. parceloxus.

The brachialis does not differ essentially from that of Gymmunand Centetes. It arises from the posterior sicle of the humerus between the two tuberosities and along the ectal margin of the erista deltoidea to insert into the capsular ligament and the inner dorsal edge of the radius.

The extensores (carpi) radialis longior et brevior (Plate 6, fig. 5, b) are not separate muscles, but form a single rather flat muscle that originates from the antero-proximal portion of the epicondylar ridge. At about the beginning of the distal third of the radius this muscle beeomes a thick tendon that passes ental to that of the extensor ussis metacarpi pollicis, and splits into two tendons that go to the bases of metacurpak 2 and 3 respectively.

The extensor digitorum communis (Plate 6, fig. 5, a) : urises by tendinous fibers from the ectal point of the epicondytus. Near the distal end of the radius it passes into a flat tendon that breaks directly into four small branches, one each to the dorsal surface of digits 2 to 5 .

Just distal to the origin of the last, arises the extensor minini digiti (Plate 6, fig. 5, g) from the ectal elge of the epicondylus and from tendinons fibers from the communis and the extensol carpi unaris. It passes into a stong tendon that elivides into two branches at the metacarpals. The ectal branch passes to the dorsal side of digit 5 and the ental branch dips under the outermost division of the communis to insert on the ecto-lateral face of the last phalanx of digit 4. This condition is essentially that in Centetes.

The cxtensor carpi uluaris (Plate 6, fig. 5, e) arises just distal to the origin of the prececling, at the outel distal edge of the epicondylus and from fibers along the greater signoid notch. At about $18 \mathrm{~mm}$. from its insertion it beeomes a thick round tendon, passing to the ecto-proximal margin of metacarpal 5 . 
In Centetes and Erinaceus this muscle is said to be inserted into a scsamoid at the lase of metacarpal 5 .

The indicator (Plate 6, fig. 5, $f$ ) arises from an origin albout 25 mm. long by muscular fibers along the ectal border of the ulna beginning near the distal erke of the sigmoid notch. The muscle then passes across to the ental aspect of the foream, through the groove between the distal ends of the radius and ulna as a flat narrow tendom. At the carpal region the tendon divides into two, the more cntal of which passes to a tendinous insertion about the dorsal base of the first phalanx of digit 1 ; the more ectal branch goes to a sinilar insertion on the cetolateral aspect of the first phalanx of digit 2. A similar condition is found in Erinaceus and Centetes.

The extcnsor ossis metacarpi pollicis (Plate 6, fig. 5, d) arises by muscular fibers along the approxinated edges of radius and una from the region of the greater signojd notch, distally to within $5 \mathrm{~mm}$. of the earpus on the kilua and to within about twice that distance on the radius. It then passes as a teudinous band, ohlicuely over the distal surface of the radius to the base of an elongated sesamoid bone on the ental side of the carpus, and to the ento-lateral aspect of the base of the first metacarpal. The relations of this muscle are said to be the same in Centetes.

The pronator teres (Plate 6, fig. 5, c) has its origin by short tendinous fibers from the epitrochlea and passes ectally as a flat shect to a long tendinous insertion on about the middle third of the dorsal edge of the proximal portion of the radius.

The flexor carpi radialis (Plate 6 , fig. $6, b$ ) is from the anterior borker of the epitrochlea, arising by tendinous fibers as a long, spindle-shaped musele. This passes into a round tendon whose insertion is at the ventral ental side of the base of metacarpal 3. Dobson does not mention this musele in Centetes, but states that in Erinacens and Potamogale it goes to the base of the second meta(arpal. Its condition in solenodun paradoxus is thus more nearly that foumd in the cat, in which a small branch passes also to the first metacarpal.

The flexor carpi ulnaris (Plate 6, fig. 6, c) arises from the intermal condyle of the humerus and is inserted by a strong tendon into the pisiform bone as in Erinaceus, Potamogale, and Centetes.

The flexm sublimis digitorum (Plate 6, fig. 6, a) is a narrow flat nuscle whose origin is wodged in between the heads of the flexor profundus digitorum. It arises as a flat tendon about $12 \mathrm{~mm}$. long from the anterior surface of the epitrochlea, about one or two millimeters from the ental margin. 'The nuscular' 
portion becomes trifid distally, and each division senels a tendon to the serond, third, and forth digits respectively. This tendon bridges the groove of the profundus.

The flexor profundus digitorum (Plate 6, fig. 6, d) arises as in Gymnura and Centetes from five heads, and thus differs from that of Potamogale in which but three are described. The first of these hearls is superficial, from the anterior edge of the epitrochlea; its large tenclon inserts into the common tendon on the radial side at the wrist. 'This division is more or less distinct throughout its distal union with the main mass of the tendon and has been homologized by Dobson with the flexor longus polliris. Two smaller muscles, forming the second and third heads, arise in close association from the anterior sulface of the epitrochlea and the anterior edge of the great sigmoid noteh. Their temdons become confluent and join the main palmar tendon medially proxinal to the insertion of the first division. 'The head of flexor sublimis separates the head of the first division from the common origin of the serond and third. The fornth head arises as a large fleshy muscle along the ectal side of the uhn from the olecranon to within about $15 \mathrm{~mm}$. of the distal end of the ulna where its fibers merge with those from the fifth division whose origin is from the proximal two thirds of the ental border of the radius. These five divisions unite to form a thick flat tendon at the wrist. This divides at the base of the metararpals to form the usual five branches, one to the lower surface of each digit. This muscle in Solenodon seems most nearly to rescunble that of Gymmura in possessing five distinct heads. In Centetes the condition is essentially similar, but the dosely associated second and third heads are united into a single division. In Potamogale the number of hearls seems to be still further reduced.

\section{MUSCLES OF THE HIND IIMHB.}

The psous mugnus (Plate 4, fig. 2, o) appoars to be essontially similar in its relations to that of Gymura, Erinaceus, and Centetes. It arises from the transverse processes of the lumbar vertebrae as a thick nuscular mass and becomes confluent with the iliacus from the ventral side of the anterior ramus of the ilium. It then tapers to its insertion on the lesser trod lanter of the femur.

The psoas parrus (Plate 4, fig. 2, $p$ ) arises as a flat ellipsoidal muscle from the ventro-lateral portion of the first lumbar and the anterior portion of the second lumbar vertebric. It then passes posteriorly as a thin flat tendon from 2 to $3 \mathrm{~mm}$. wide and $30 \mathrm{~mm}$. long to insert on the anterior edge of the pelvis, just 
anterior to the origin of the pectineus. This muscle is thus elosely similar to that of Erinaceus, Centetes, and Myogale, having apparently much the same proportions, origin, and attachment. In Potamogale and Gymnura it is very much larger in relative size and extent of origin, and is remarkable in the latter on account of its insertion upon the lesser trochanter together with the psoas magnus.

The gluteus maximus (Plate 6, fig. 1,e) arises as a thin museukar sheet by tendinous fibers along the dorsal border of the ilium and the dorsal spines from the fourth lumbar to the first eaudal vertebra. A very distinet and separate portion of this musele (Plate 6 , fig. $1, m$ ) arises from the anterior tuberosity of the ilium, just back of its dorso-lateral edge and passes postero-rentrally to join the anterior edge of the main mass of the maximus about a centimeter corsal to the common tendinous insertion into the prominent erest below the great trochanter and some $15 \mathrm{~mm}$. from the head of the femur. This peentiar second head may be an anomaly. Dobson does not mention it in his aecount of the museles of Solenodon cubrmus. In Gymnura the gluteus maximus is deseribed as having a continuous origin "from the whole anterior margin of the ilium," a condition from which that in Solenodon just described might readily be derived.

The gluteus medius (Plate 6, fig. 1, b, n) arises as in Gymnura, Erinaceus, and apparently Centetes, from two heads, here, howerer, with diffieulty distinguishable, from the entire outer face of the anterior portion of the ilium as far back as the level of the third saeral vertebra. The more anterior part is thick and fleshy; it inserts by tendon on the antero-dorsal portion of the great trochanter. The more posterior division inserts somewhat more distally on the posterior part of the great trochanter. The great seiatic nerve takes exit at the hinder margin of the first part of this muscle and is slightly overlapped by the second.

The gluteus minimus (Plate 6, fig. 1, a) is small and flat, from an origin about $14 \mathrm{~mm}$. in length on the ischium beginning just above the acetabulum. It is inserted by tendinous fibers on the great trochanter, entero-posteriorly to the two other glutei. This muscle agrees with that of Gymmura in its more posterior origin; in Erinaceus it arises from the ilium.

The reetus femoris (Plate 6 , fig, $1, l$ ) is from a short tendinous origin some $4 \mathrm{~mm}$. long from the postero-ventral margin of the ilium just anterior to the acetabulum. It is inserted on the antero-internal edge of the patella.

The rastus externus (Plate 6, fig. 1, k) has a long origin from the great trochanter and the trochantal ridge nearly to the distal end of the femur, and 
passes into a tendinous insertion on the cetal sile of the dorsal margin of the patclla.

The crureus (Plate 6, fig. 1, j) arises along the anterior margin of the fomur and is almost inseparably united to the vastus externus. It inserts medially on the patella beneath the insertions of the rastus cxtcrnus and the rectus femoris.

The rastus internus (Plate 4, fig. 2, b) is distinct, instead of being fused with the crureus as in Ciymuma. Its origin is from the antero-ental side of the proximal third of the femur, and its insertion is at the ento-dorsal coner of the patella.

The pectineus (Plate 4 , fig. '2, $n$ ) is a thick muscle somewhat triangular in section. Its origin is just dorsal to that of the adductor longus for about 9 mm. on the anterior rim of the pelvis and posterionly nearly to the acctabulum. It is visible superficially for but a slight space, and passes beneath the surrounding muscles to its insertion as a somewhat tendinous sheet on the inner posterior length of the femur from the lesser troehanter nearly to the distal head. It is thus slightly more developed than in Gymnura.

The quadratus femoris (Plate 4, fig. 2, $h$ ) is large, from an origin $19 \mathrm{~mm}$. long on the posterior edge of the ischial tuberosity, covered by the adductor magnus and the semitendinous. It is inserted by a tendon on the lesser trochanter and the intertrochanteric fossa. Its relations are closely similar to those in Potamogale and Centetes. No connection with adductor brevis was found such as is rescribed for Gymmura.

The obturator extermus arises from the membrane covering the obturator foramen and from the bone bordering it. The insertion is by tendon into the trochanteric fossa posterior and ental to the great trochanter. This muscle is essentially similar to that of Gymnura, Centetes, Potanogale.

As pointed out by Dobson, Solenodon differs from c'ntetes and agrees with Cymmura, Potanogale, Erinaceus, and Myogale in the alssenee of an obturntor internus.

The graeilis (Plate 4, fig, 2, g) is large and ariscs from the dorsal half of the posterior margin of the ischium. It is somewhat pyramidal at first, becoming a flat muscular sheet just below the head of the tibia along its antero-intemal border. As noted by Dobson, the gracilis muscles of the two sides of the body are well separated in Solonodon and related genera, but united medially in Centetes. No accessorius portion of this muscle was observed.

The bieeps femoris (Plate 6, fig. 1, i) is from two heads. Of these, the larger is from the ischial tubcrosity, white the smaller consists of a flat tendinous men- 
brane from the spines of the two first caudal vertebrae. The two branches shortly unite to form a broad thin tendinous sheet that inserts on the ectal portion of the head of the tibia and condyle of the femur. Its condition is thus practically as in Gymmura. In Centetes and Potamogale the insertion is upon the fibula.

The semitendinosus (Plate 6 , fig. $1, d$ ) arises in a somewhat similar way by two heads: one by tendinous fibers from the dorsal spines just posterior to the origin of the dorsal branch of the bicess; the other from the tuberosity of the ischium posterior to the biceps. These two heads unite to form a single sheet of muscle that passes to an insertion some $9 \mathrm{~mm}$. in length on the antero-ental side of the tibia, 22.2 mm. below its head. It resembles the same musele in Centetes, Potamogale, and Myogale, rather than in Gymnura.

The semimembranosus (Plate 4 , fig. $2, d$ ) is very large and divisible into two portions. The first is a narrow hand from the postero-rentral portion of the tuberosity of the ischim, passing to an insertion on the inner distal tuberesity of the femule. The second portion is the larger, and arises from the entire posterior border of the pelvis. It is inserted by short tendinous fibers on the ental aspect of the tibia for a distanee of $11 \mathrm{~mm}$. from its proximal head. This musele is essentially like that of Centetes in its attachments. In Gymmura and Potamogale it is less extensive in origin and has but one head.

The sartorius is absent, as also in Centetes and Potamogale acrording to Dobson, who found it feebly represented, however, in Grmmura. Leche (:02) considers this muscle well developed in the last named.

The four adrluctores are well developed and quite separate. The adductor longus (Plate 4, fig. 2, e) is a rather narrow hand, arising from the anterior edge of the pubis, just ventral to the origin of the pectineus. It inserts as a tendiuncus sheet on the cutal surface of the innel condyle of the femur. Dobson describes in solcnodon cubomus a soreond small slip passing to the fermur at the middle third of the slaft, but no such part was found in s. paradoxus, which therefore resembles Potamogale in respect to this musele. In Ciymmura and Centetes, however, Dobson deseribes a kong insertion nearly the whole length of the femur, so that the condition he describes in 5 . cubamus is intermediate between that of Gymmura and Centetes on the one hand, and S. paradoans and Potamogale on the other.

The adductor brevis (Plate 4, fig. 2, e) arises under cover of the gracilis from the rentril portion of the pubis and ischium. It is inserted by tendinous fibers for a distance of about $10 \mathrm{~mm}$. along the distal third quarter of the femur on its 
posterior side. This muscle in Centetes is sinilar but with a rather more extensive distal insertion, while in Crymurat the insertion is nearer the proximal end of the fenur.

The adductor magnus (Plate 4, fig. '2, $m$ ) is small. It is a thin narrow strip arising from the tuherosity of the ischium under the biceps, and passes to an insertion under cover of that of the adductor longus on the internal condyle of the femur. This muscle shows a less developed condition as compared with that of Gymmura and Centetes. The peculiar insertion into the inner head of the gastrocnemius described by Dobson in Potamogale, he believes is a special modification eorrelated with the animal's habit of drawing the hind leg up against the tail when swimming.

The origin of adductor quartus (Plate 4, fig. 2, $k$ ) is under cover of that of adductor brevis from the ventral portion of the pubsis and ischium, but its posterior extent is less at the ventral margin. It increases slightly in breadth as it passes over the lesen trochanter to insert on the proximal thind of the femur along the ento-posterior side of the great trochantal ridge nearly to the proximal insertion of the adductor brevis. In Centetes and Potanogale according to Dobson, this muscle presents the same relations, hut it appears to be alssent in Gymmura.

The gastrocncmius (Plate 6, fig. 1, e; fig. 4) is a large muscle arising by two heads as usual. The first is from the pusterior side of the external condyle of the humerus, by a stout tendon in which there is a small sesamoid bone; the second is from the internal condyle just proximal to the iusertion of a portion of the semimembranosus to which it is joined by a few fibers. The great nerve trunk of the leg passes between these two heads. The insertion is as usual by the tendon of Achilles into the calcaneum at its posterior end.

The soleus (Plate 6, fig. 4, a) shows an interesting relation, and one apparently not observed by Dobson in Solenodon cubanus. It ariscs by tendinous fibers from the ecto-posterior edge of the head of the fibula, and becomes fused with the ectal portion of the gastroenemins above its passage into the tendon of Achilles. A similar condition is found in Gymmura and Potamogale, but apparently not in Centetes.

The plantaris resembles that of Centetes in being inseparable from the gastroenemius at its origin. Its tendon is apparent, howerer, on the ento-lateral side of the gastrocuemius. In Gymnura and Potamogale the origin is described as distinet from that of the latter.

The popliteus arises as usual from the thick tendon investing the ectal side 
of the condyle of the femur. It passes obliquely as a triangular musele to insert upon the postero-ental surface of the tibia just proximal to the origin of the tibialis posticus. There is a large sesamoid in the tendon of origin, attached by fibers between the heads of tibia and fibula.

The tibialis anticus (Plate 6, fig. 1, h) arises from the large shallow fossa on the ectal side of the tibia and the adjacent portion of the fibula. The muscle is triangular in section and becomes a strong flat tendon distally, that passes to the cntal side of the foot through the same loop as the extensor longus digitorum. It is inserted on the ento-lateral side of the base of the entocuneiform bone, not on the rudimentary first metatarsal as in some mammals, $c . g$, the cat, or the metatarsal of the first digit as in Crymmura, Potamogale, and apparently Centetes. Dobson does not mention the comnections of this muscle in Solenodon cubamus. In s. puradoxus, howerer, this termination was earefully verified on both hind feet. The inserting tendon is large and conspieuous and is inserted back from the anterior edge of the bone.

The extensor longus digitorum pedis (Plate 6, fig. 1, $g$ ) is a very small narrow musele, hardly $2 \mathrm{~mm}$. in radial thickness, and less than that in superficial breadth. Its origin is from the tendinous sheath covering the eetal aspect of the condyle of the femur. Its tendon passes through a loop on the anterior part of the ankle together with the tendon of the tibialis anticus, then through a second loop enclosing the extensor alone, which here has broken into four appressed thread-like branches, one to each of the digits, 2, 3, 4, and 5. The branch to digit 5 is inserted at the ental, the others on the dorsal aspect of their respective digits. A similar arrangement is described for Ciymmura and Centetes.

The peroneus longus (Plate 6 , fig. $1, f$ ) is very distinctly from two heads. The first is from the tendinous sheath corering the external condyle of the femur, eontinuous with the origin of the extensor longus digitorum. These tendinous fibers pass across to the second and principal origin about the head of the fibula. At a little more than one half the length of the tibia the muscle passes into a slender tendon, which dips under a loop at the ectal side of the ankle, then under a second loop on a prominence at the ceto-anterior portion of the calcancum. It then gives off a small branch to the base of metatarsal 5 and continues across the foot to the insertion into the base of metatarsal 1. In Gymnura and Erinaceus curopaeus it is merely inserted into the internal cuneiform, but in E. jerdoni aceording to Dobson ('82-'90, p. 5.5) the braneh to the fifth metatarsal is also present. The insertion into the first metatarsal seems 
to be a peculiarity not hitherto noted, but was ummistakably present in $S$. paradorus and may be anomalous.

The peroneus brevis and the peroneus quinti digiti arise on the antero-external aspect of the fibula, the latter from the external as eset for a distance of alout $11 \mathrm{~mm}$. distal from the head, and the former more internal, for a slightly greater distance. The tendons of both are invested in a common sheath and pass together posterior to the external malleolus and bencath the tendon of peroneus longus. Peroneus quinti digiti is inserted into the distal phalanx of digit 5, while the peroneus brevis passes to the ecto-proximal end of the fifth metatarsal. Both these tendons are simple and show no trace of secondary divisions to digit 4 as described for Gymnura and Centetes by Dobson. Solenodon thus resembles Potamogale in the single attachments of these musces.

The extensor hullucis longus arises from the midllle third of the filmla and adjacent interosseus ligament and passes to the distal phalanx of digit $1 \mathrm{om}$ the dorsal side, through the sanne large groove on the front of the ankle, as the extensor longus digitorum and the tiljialis anticus.

The tibialis postieus (Plate 4, fig. $2, j$ ) is concealed by the flexor longus digitorum. It arises from the proximal end of the fibula on its posterior side and is more or less connected by museular fibers with the flexor longus hallueis. After crossing to the ental aspect of the limb, it passes as a small tendon through a groove on the distal part of the tibia to the insertion into the ento-lateral process of the os calcis at its anterior end, not into the naviculare or scaphoid as commonly. Dobson states that this muscle in Solenodon cubanus retains its usual insertion into the naviculare, but in s. paradorus it was found on cach side, inserted unequivocally as above noted.

The flexor longus digitorum, or digitorum tibialis (Plate 4, fig. 2, l) arises mainly from the posterior proximal portion of the tilia. The tendon passes through the same groove on the ental aspect of the tibia as that of the tibialis posticus, and ectal to it. It becomes inserted into the ventral surface of the flexor longus hallueis. At the base of the carpals, it gives off a small branch to the rudimentary first metatarsal. This muscle in Solenodon resembles the corresponding one in Potanogale, rather than that of Centetes whose curious development has been described by Dobson. In Gymnura it is merely united with the next.

The flexor longus hallueis (or digitorum fibularis) (Plate 4, fig. 2, i) takes origin from nearly all but the distal portion of the posterior sicle of the fibula and adjoining middle third of the tibia. It is nuch larger than the flexor 
digitorum tibialis. Distally it passes into a strong tendon that runs along the ventral groove of the os calcis and spreads out over the sole of the foot. Here it is joined by the tendon of the flexor longus digitorum or tibialis and then sends a large tendon to the rentral surface of each digit.

Two short stout tendons bind the foot to the bones of the lower limb. The one is from the distal enc of the fibula at its ectal margin and passes to the dorsal edge of the os calcis posterior to the articulation with the astragalus. The second tendon is on the cntal side from the anterior erlge of the tibia to the proximal end of the naviculare.

\section{IIUSCLES OI THE TAIL.}

The tail of solenodon is eapable of almost no lateral movement, but may be slightly elevated and depressed. In section it is nearly quadrangular proximally after the skin has been removed to expose the muscle masses. These are ahiefly four.

The levutor cundae interms is the most dorsal, and is continuous with the semispinalis of the back. It passes dorsal to the metapophyses, and breaks into tendinous threads that form a distinct bundle rumning the length of the dorsal side of the tail. On the distal two thirds of the tail these tendons becone insorted on the anterior zygapophyses. This mass of fibers is joined hy small tendons from museles that arise from the metapophyses of the caudal vertebrae and by others from the dorsal portion of the vertebrac between the spines and the zygapouphrses. The tendinous bundle resulting from these fibers, tapers to the extremity of the tail and forms the dorso-lateral angle of the tail.

The levator ecudue cxtermus is smaller. It is a bundle of small museles that arise by tendons from the median edge of the anterior portion of the ilimm and from the metapophyses of the sacrum. These unite and pass distally as a thin hateral bundle connecting the metapophyses of the caudal vertebrae.

The ventral musculature of the tail is mainly from the sacro-eoceyyei, one on either side of the mid-ventral line, below the metapophyses. These arise each as an elongated mass from the ventral side of the sacral vertebrae, medially. Just distal to the ischim they pass into strong tendinous strands that shortly form a rounded compact bundle, tapering to the distal end of the tail. This bundle forms the ventro-lateral angle of the tail on each side as seen in section, and fills the space between the chevron bones and the metapoplyses.

Ventrally a small muscle arises from the posterior end of each cherron bone 
on either side. It passes externally to the next posterior chevron bone as a small tendon and inserts into the antero-ventral end of the cherron bone next sureceling. Fach muscle therefore skips one chevron bone and inserts upon the next but one posterior to its origin.

\section{OSTEOLOGY.}

The cranial characters of Solenodon are now well known. The original skull described and figured by Brandt ('33) was ineomplete, having lost the ocripital portion. In his recent paper on this animal, Dr. J. A. Allen (:08) has given photographic reproductions of the skulls of old and young. The superior outline of the skull is nearly flat, becoming slightly depressed posteriorly. The sagittal crest is slightly developed on the posterior half of the skull but in the specimens eximined was barely over a milliumeter in greatest extent vertically over the condyles. The lambdoid erests are greatly developer and overhang the foramen magnum about $5 \mathrm{~mm}$. The maxillary region increases gradually in depth from bohine the large first incisors to the molars, where it aloruptly deepens to the last molar. This depth is retained to the mastoid region, then hecomes slightly less. The lachrymal foramen is very large, and only $2 \mathrm{~mm}$. dorsal to the great antorbital formen. There are several $(t$ or 5$)$ small foramina above the mastoid process for the passage of vessels. In dorsal aspect, the most striking peculiarities of the skull are: the deep cmargination of the nasals, with their median point some $4 \mathrm{~mm}$. posterior to the anterior end of the intermaxillaries; the long. parallel-sided snout, oceupying slightly more than one third the length of the skull; the elongated brain-ease, slightly rontracted at the middle of the orbit, then expanding at the mastoid region and ending in a faralle-sided and abruptly truneated oeciput. There is a diastema between the first and reecond incisors, at which point is a depression on cach side in the flem of the patate. The two incisive foramina are at the medial border of each pit, and measure $2 \mathrm{~mm}$. in length. The palate is nearly parallet-sided on the rostral portion, and expands distally. Ninute foramina oceur at the ental bases of the teeth and posteriorly near the median region but otherwise the palate is entire in our specimen. The interuterygoid fossa is deep, and slightly ennvergent posteriorly, thus rliffering from that of $\mathrm{S}$. cubanus in which these walls diverge. The hamular processes of the pterygoids are short but sharply con-

'Sincts this account was prepared, W. I. Grenory has puldished a deseription of the skeleton of s. marulixus (we bull. Amer, mus. nat, hist, 1910, 27, p. $241-265)$. 
vergent. A small projection of the palate forms a minute tooth medially at the posterior edge of the palate. The tympanic bone is a nearly conplete narrow ring, not fused with the mastoid portion of the periotic, but meeting it for a space of about $3 \mathrm{~mm}$. along the ecto-posterior edge. At the antero-lateral termination of the tympanic is the large fissura Glaseri as a groove on the posterior side of the post-glenoid process. There are two large formina between the ental end of the latter and the pterygoids, the more anterior of which alplears to correspond to the foramen rotundus and the more posterior, which is slightly the larger, to the foramen ovale. The zygomata are ineomplete. The round flat bone, fastened by ligament to the anterior end of the intermaxillaries at the ventral edge of the nasal cavity was noted and described by Brandt in his paper of 1833 . It serves to support the base of the cartilaginous proboseis and was termed by Brandt the os proboscidis. It is lacking in Solenodon cubanus. It is nearly circular and about $5 \mathrm{~mm}$. in diameter in our specimen.

The teeth have been thoroughly described by Brandt, Peters, Dobson, Leche, and more recently by J. A. Allen, who has figured the milk dentition. The tooth formula is $I_{\frac{3}{3}}\left(\frac{1}{1} \mathrm{P}_{\frac{3}{3}}^{\frac{3}{3}} \mathrm{I}_{\frac{3}{3}}\right.$. In addition to the smaller size of the teeth, those of the Cuban species differ conspicuonsly in the presence of a diastema nearly $2 \mathrm{~mm}$. long between the third upper incisor and the canine; in the absence of an anterior cingulum eusp on the upper canine; and in the form of the second upper premolir, which in the Cuban animal has a prominent ento-posterior angle giving a nearly triangular basal section to that touth, whereas in solenodon paradoxus this angle is not developed and the tooth is nealy oval in outline. All the teeth of the lower jaw are in contact in both speries. The last lower molar of S. paradorus shows a slightly greater relative development of the posterior eusp than that of s. cubanus. The remarkable resemblance in the form of the skull and treth of Solenorlon to those of Myogale was noted by Brandt. The general rosemblance in external form as well, suggests that in these respects Myogale is a generalizol member of the Talpidate that has arequired a further development of the molariform tecth from the prinitive tritubercular endition of the crowns to the nore specialized $I V$-shaped type of crown. In these respects and in certain points of muscular development, Myogale probably stands in much the same relation to the rest of the Talpidae as does Cirmnura to the others of the Erinaccidae. Both are generalized forms bearing many close resemblances to the more primitive Solenodontidae.

The remarkable deep groove of the large second lower incisor of Solenodon seems peculiar to this genus. In Erinaeeus there is a slallow groove on the first 
incisor at the internal side of the tip and a similar eondition exists in the second lower incisor of Talpa.

The vertebrac of Solenodon paredoxus are: ecrvicals, 7; dorsals, 16; lumbars, 4; sacrals, 4; cuulals, 24; total, 5i. There is thus one more clorsal, one less sacral, and one less eaulal than deseribed for s'. cubamus by Peters, whose areount appears to be the only one on which our knowledge of the skeletal parts of S. cubamus other than the skull, is based. Dobson apparently follows Peters, though he states that his description of the myology is based on the dissection of a specimen from Cuba in the P'aris Museum. Peters's figure is very clear, and the additional sacral vertebra in cubanus seems to be a caudal fused to the sacrum since the first chevron bone is between this fused rertebra and the next following caudal vertebra instead of between the first and second free vertebrae. In possessing 16 dorsals, Solenodon paradoxus resembles Potamogale. Gymnura has 15, as does S. cubamus, and certain species of Erinacens. Centetes seems still more primitive in possessing 19, as does Chrysochloris. The lumbar vertebrac in Solenodon are reduced in number as in the latter genus, being but 4, and thus fewer than in the other generalized Insectivora. Centetes is remarkalle in possessing lout two sacrals, though solenodon paradoxus with four only shows a reduecd condition as compared with related genera. The following table will show at a glince these differences.

\section{Vertebral Formulae of Insectivora.}

Gymuna alla

Erinacels

Tulpa

Myogal

Potamogile . . . . . . . . . .

('intetes

Solenerlon culsunu

Solenoton paradoxus

chrysorliloris

\begin{tabular}{|c|c|} 
Crrvieals. & Dorsals. \\
7 & 15 \\
7 & $14-15$ \\
7 & 13 \\
7 & 13 \\
7 & 16 \\
7 & 19 \\
7 & 15 \\
7 & 16 \\
7 & 19
\end{tabular}

\begin{tabular}{c|c} 
Sacrals. & Caudals. \\
5 & 25 \\
7 & $6+$ \\
5 & 12 \\
6 & 27 \\
5 & 22 \\
2 & 7 \\
$5 ?$ & $23 ?$ \\
4 & 24 \\
5 & $8-9$
\end{tabular}

The athes of Solenodon (Plate 7, figs. 4, 5) rescmbles that of Gymnura in possessing a ventral median hypapophysis extending posteriorly from the anterior lip, but the remaining vertebrae are without hypapophyses, thus differing from Gymnura and Potamogale. The axis is large with a high broad crest and elongated transverse processes at its ventral margin, directed posteriorly (Plate 7, figs. S, 9). At the fourth cervieal vertebra the transverse process has also an anterior projection which increases somewhat in the two sueceeding. 
In the 6th rertebra this proess is produed axially forming a broal rentrolateral ridge extending posteriorly beyond the edge of the vertebra itself. This condition is found in Gymmure albe of which a skeleton was examined. In Erinaceus the posterior extent of this process is less. In the seventh cerviral this large puress is nomally obsolescent, but in one example of Solenodon paradoxus examined, it is equally divided between the 6th and the 7th ecrvieals so that a vertebral canal is abnormally present on the left side of the 7 th cervical, but not on the right side.

The doral vertebrae in a general way resemble closely those of Gymnura. The spines of the three first dowals increase sucessively in height, and measure from the anterior end of their proper bases, 11.5, 16, and 17 mm. respectively. These spines are high and somewhat circular in section, and expanded a trifle distally. In Gymnura the spine of the second clorsal is highest. The following spines from the fourth to the ninth decrease slightly in height, and become stouter and laterally compressed. All of the series are directed sharply backward. The spines of the tenth, eleventh, and twelfth vertebrae, however, are harlly tapered distally and eurve distinctly forwat at their tips. The thirteenth spine is nearly upright and the fourtecenth is almost twice its length and points anteriorly. The two last dorsak have low spines whose tops are flat in profile and nearly as long as their centra.

The twelfth dorsal vertebra begins to develop a desending lateral point at the proturiorend, that becomes a distinet diapophysis at the 14 th vertebra and in the vertebrae suceeding. Beginning with the first hmbar (Plate 7, figs. 13, 14) howeres, the diapmhysis instead of being direeted posteriorly, is curved anteriorly from a base lunuing the length of the vertebra on a level with the cented of the spinal eord.

The four sacral vertoluac are solidly fused throughout, mueh as in Gymnura, and the eontimuation of the diapenhyses forms a flange or shelf along the sides of the eentra. The dorsal profilo is slightly emarginate hetween suceessive spines of the fused rertehrae. The sacrum, in domal riew is narrower near the midelle of its length than at cither end.

The caudal vertehrae (Phate 8 , figs. 3, 4, 6) rapidly lose their dorsal spines, which are well developed in inly the three first. The neural canal practically disappears with the minth. The prezygapophyses of the fifth caulal are the last to form an articulation, for this and the suceeding vertebrae lack any trace of postzygapophyses. The prezygapophyses become sucessively reduced toward the tip of the tail, and become obsolete on the 16 th or 17 th vertebra. 


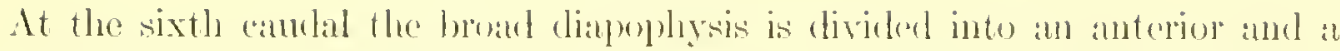
posterior pertion, the latter of which becomes obsolete at the 15th, and the

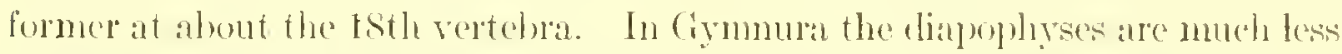
developed, having an anterior hut not a pesterior origin on calch vertebua, while the prezygapophyses, in the specinen examined, end with the third catudal.

The cherron bures are laredy dereloped, and as in Gymmura oecur in connection with all hut the few terminal vertebrac. In ciymura, howerer, the two lateral elements of each cherron are mufused except in wase of the secomel and third which are united at their origin modially. Their anteroposterior extent is much greater in Gymmun. In solenolon the two lateral elements of the first eheren are thin terete spicules of bone, approximated distally but separate. The second cheven is similar hut the two dements are fused both proxinally and distally forming a dosed canal for the waulal artery. The same comblition prevals in the two following, whose distal parts are in addition exlameded latterally. In all the suceceding cherrom bones the arterial canal is open ventritly: The list drevon is between the 21st and the 22d caudals. In Solenolon cubomus l'cters has figured but twenty chevron bones. There are 21 in s. prododoxus.

The ribs and sternum (Plate 7, figs. 11, 12) of Solenodon are remarkably strong and well ossified. The stemat portions of the first twelve ribs are bony, while the thirternth is cartilaginous at the distal end only. The two suceectiner libs ane connerted by a cartilaginous strand to the ventral margin of the other stemal ribs, while the loth rib is short and without such connection. The sternal portion of the first rib is broad at its articulation with the manubrium along the posterior "urve of its antero-lateral expansion. The stemal portions of the three rits following articulate each at the point of union of the first and second, secomel and third, and third and fourth sternal elements respectively The fifth rib is inserted at the junction of the fourth and fifth stemal elements, and its stemal portion is of two separately ussified pieces. The fifth stomal element serves for the attalehment, directly or secondarily of ribs 6 to 14 both inclusive. The sixth and serenth ribs are inserted separately, one directly in front of the other; the latter has three bony portions ventral to the main dorsal shaft. The stemal portions of ribs $8,9,10$, and 11 , have cach a proximal section about $13 \mathrm{~mm}$. long, making nearly a right angle with the more distal portion running antero-internally to the stermm and forming the rential rim of the thoracic basket. These more listal pieces of these ribs just mentioned, are fused into a single bony matsi, on whose ectal surface may be traed the lines of union, 
though on the ental face these lines eamot be seen. In Cymnura the sternal eartilages of but two ribs, the Sth and the 9th, are partly fused in this way. The terminal cartilages of ribs $12,13,14$, and 15 , are bound by connective tissue to the posterior rim of this large fused mass in Solenodon paradoxus. The extreme development of the sternal portion of the rils in Solenodon is very remarkable and apparently not found in other Insectivoris. In a skeleton of Ericulus setosus from Madagasear, however, a somewhat similar ossification of the sternal portions of the ribs is present, but there is not the fusion of the rentral elements in the posterior members.

The first thirteen rils have a double articulation: by the eapitellum to the point of union of the vertebra with the vertebra next preaceling; and by the tuberenhun to the lateral surface of the prezyganophysis. 'The tubereulum disappears with the fourtecnth rib and the articulation is at the anterior end of the centrum of the respective vertebrac alone, not with the centra of two vertebrac.

The sternum is of six pieces. The manubrium is lomblly expanded anteriorly. It is not keced, but is slightly cmarginate at the median extremity. It thus resembles that of Erinaceus and Ericulus, and differs matkedly from that of Gymmura which is lozenge-shaped anteriorly, with a strong keel. The three stemal pieces following the manubrimn are quadrilateral, each slightly longer than wide and narrower at the anterior end. The fifth piece is evidently a fusion of three elements, the last of which is the most reduced in width. 'The flat narrow teminal element (xiphistermum) is articulated to its dorsal posterion margin and bears a latge ovial cartilage distally.

Compared with the sternum of Solenodon cubomes as figured and described by Peters, that of si. paradoxus differs notably in possessing one less element. There ate seren sternal pieces in the former and but six in the latter. This difference seens clarly to be due to the complete fusion in s. paraloxus of what in S. cubonus are the fifth and sixth pieces, so that in the former the penultinate element of the stemum gives attarehment to three sets of rihs instead of but two as in the latter. The absolute length of the articulating segments of the stermum is thus some $6 \mathrm{~mm}$. shorter in S. paradoxus than in the Cubin species, notwithstanding the greater general size of the former. A seeond difference is found in the shape of the xiphioid process which in s. paradoxus is simple, whereas in S. cubemus it is represented as of two lateral portions fused anteriorly.

The clavieles are large and slightly signoid in anterion aslect. They are united by membrane to the antero-intemal extremities of the manubrium and curve, dorsal to the head of the humerus, to the dorsal adge of the tip of the acromion. 
The pelvie girdle (Plate 8, figs. 1, 2) is much like that of Erinaterus in its proportions. The pulis is well developed, with a lateral arest for the attachment of muscles, and quite without the inward arehing of the anterior rim so peeuliatly devaloped in Crymumat. The symphysis is about $4 \mathrm{~mm}$. long yet firm, as in Erinaceus. In fymmura it is incomplete. The obturator foramen is large and subquadrate in wutline. The ischial tuberosities are about as far apart as are those of the ilia. In absolute size the pelvis of solenodon paradoxus is practically identioal with that of st. cubrmus. Leche (:07, p. S3, text fig. 7\%) has given a figure and description of what he believed to be "das bisher unbekimnte Becken von , vol. pararlorus," but there can be no dombt that the bones

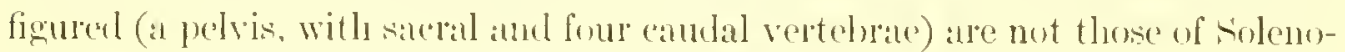
don at all. The figures represent a pelvis langer than that of this genus, with a

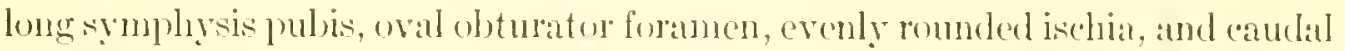
vertebrac of a totally different charateder from those found in Solenodon. Doubtless the mistake arose througl some transposition of labels, for Leche himself remarks upon the astonishing chatraters that the specimen presents, quite different from those of all other "Insectivora lipotynhla."

The scapula (Plate 8, figs. 5, 7, 8) is subtriangular in outline, with a greater relative develomment of the coracoid nargin than in Erinateds. The seapula spine is broad and sledf-like but the acromion and metacromion are shorter than in Erinacess and Gymnum, and in this respect resemble these processes in Centetes.

The humerus (Plate 8, figs. 9 11) is short and is remarkable for its great expansion distally, on each side of the articulation. The epitrochlear foramen is present as in Grmmura, Centetes, and Ericulus. This formmen is absent in Erinaceus. In the specinen of Gymura eximined, the olectanal fossa is perforate, but no such perforation was found in Solenodon, Ericulus, or Erinaceus, and it apparently does not exist in Centetes. The extreme length of the humerus is $49 \mathrm{~mm}$. or about $5 \mathrm{~mm}$. longer than that of $\mathrm{S}$. cubames; its least breadth is $5 \mathrm{~mm}$. at about the commoncement of the distal third of its lengrth. The greatest distal expansion is $15.5 \mathrm{~mm}$., of which the articulating surfare occupies $7 \mathrm{~mm}$.

The radius and una (Plate 8 , fig. 15) are separate and practically as in the Cuban solenodon. The former is narrow proximally with a distinct neck about $5 \mathrm{~mm}$. from the articulation. Distally it is expanded and articulates with the radiate and the intemedimm of the carpus. Its ectal face has a shallow longitudinal groove along the clistal three fourths. Its extreme length is $41.5 \mathrm{~mm}$., or about $5 \mathrm{~mm}$. greater than the measurement of the same bone in Peters's 
figure of s. cubumes. At its proximal end it is in contact with the uhat for at distanee ol 6 mmon. along the lesser sigmoid cavity. The ulna is more slender in proportions and tapers distally. At the carpus its ental siele is in contalet with the radius, and it articulates with the unare. A deej groove commenees bedow the signoid notch and rums nearly the entire length of the ectal face, heoming shallower distally. In Gynmura and Erinacens, skeletons of which were arailable for clinect comprorison, this groove is but slightly developed. I nuch shallowere groove is present on the ectal face of the uhual, but is batrely indicated at the proximal end in the two genera just mentioned. The extreme length of the ulna is $54.5 \mathrm{~mm}$., and thens but 2.5 longer than that indieated in Peter's figure, natural size, of the skeleton of S. cubemus.

The carpus of solemodon (Plate 8 , fig. 15 ) is ol' a very generalized chatratere, and appears to be nearly identical in the two speciesof the grents. The proximal row of ossides consists of radiale, internedium, and ulnare, the two first ol whireh lie side by side and articulate by their proximal faces with the radius; the ulnare is an isosceles trimegle in dorsal outline, and articulates with the uluat only at its proximal side, while the base is in contact with the internedium. The radiale has the greatest lateral extent of the three, and at its ental margin is produeed as a rounded knob on the ventral side. A slight sulcus near the distal end of this projection may indieate a fused basal portion of the prepollex. The os centrale is a small compressed bone mainly in contart with the radiale but (n) its ecetal margin touching the centrale and the third carpale. The distal row of carpals is of four bones, of which the most ectal or uneiform represents as usual the lused fourth and fifth carpalia; it serves for the articulation of the fourth and fifth digits. The first, second, and third carpalia alle separate bunes, and give articulation to their respective metararpals. The second metalcalpal, lowerer, has also a short articulation at the inner side of its base, with the first carpale. The prepollex is about $6 \mathrm{~mm}$. long and nearly 2 mun. in greatest width; it is looscly attached by comnective tissue at the base of the first digit. The pisiform bone is strongly developed at the ectal side of the carpus, and articulates with the uhnare and slightly with the distal point of the ulna.

In the generalized condition of the carpus, Solenodon paradoxus resombles Centetes, but is even more primitive in that it retains the radiale and the intermedium distinct instead of fused into one as in the latter. Aceording to Dolson these $t$ wo bones arre fused in S. cubanus ("There is at s(apho-lunar bone") but Peters's figure shows them as two scparate ossicles. Ciymmura and Potanogale in aldition to the fusion of these bones, show a further reduction of the carpal elements through the loss of the os centrale. 


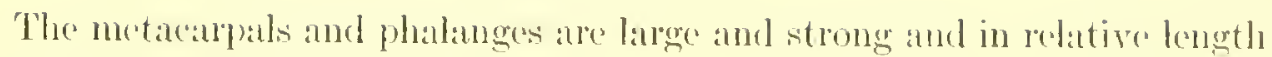
woukl be arranged in the ordere 3, 4, 2, 5, 1. 'The midlle three dierits are subequal, and have each three phalanges. The first and fifth digits are conspionotsily shorter; the former has but two phalanges, but the latter has three. The claws are shorter in S. peradoxus than in S. cubonus, A pair of small sesamoids is present ventrally at the proximal end of the first phatanx of each dignit. These as ustual, form a groose for the great flexor tendon. A single modian sesamod is also puesent at the rentral articulation of the two terminal phatumges of each digit. In the pollex, howerer, it is very small.

The lemur (Plate 8, figs. 12, 13) is mueh like that of cymmura in shape lut has a shorter shaft. Indeed, the shortness of the femm is remarkalle. The lesser trochanter is about as well developed as the greater. A deep fossa oceurs on the posterior side of the katter and is continuous with the broal intertrochatnterie depression. A conspienous sesimoid is present on the extal side, at the postcrior curve of the distal condyle; it lies in the ectal tendon of the gastrocnemius. The large, subquadrate patella neasures $7.5 \mathrm{~mm}$. in length. The greatest length from the proximal to the distal condyle of the femur is $47.5 \mathrm{~mm}$.

Dobson states that in solenodon cubanus the tibia and fibula are listinct, as in Centetes, Ericulus, Hemicentetes, and Tupaia although so closely approximated in the distal third that they might ankylose in aged individuals. Peters's figure also shows the two bones distinet in this speces. In the achult s. puredoxus, however, the two are mited distally for $18 \mathrm{~mm}$, or about one third their length. The line of lusion is discruible, nevertheless, and a deep growere is formed between them, for the peroners tendons. This point appears to be one of some importance, for all previous writers have emphasized the separation of tibia and filmla in folenohom as a character possessed in common with Centetes, but not found elsewhere in the related families. It is not elear that the condition as thus described for r. cubunes is due to immaturity or individual variation, but certainly in adult s. paradoxus, the tibia and fibula are distally ankylosed its in J'otamogale, exeept that in the latter the line of mion is said to becones quite obliterated with age. It should be mentioned, however, that in the sketeton of a young s. paradoxus examined, the tibia and fibula, though clesely approximated distally are apparently separate, and in the skeletons of two fully grown thengh not ohl animals, these bones are but inperfectly fused along the line of cont act. The antero-internal face of the tibia is lat her flat proximally, but the crest at the ectal border of this flattened area is scancely developed, in contrast with the condition in Gymmura in which a prominent crest projects 
over a deep fossa. The fibula is of about the same absolute width as in Giymura and articulates at its head with the ectal head of the tibia. It is therefore free proximally as, apparently, in Potamogale and Myogale, hut not in Gymuura and Erinaceus. An oval sesamoid bone about $3.4 \mathrm{~mm}$. in length oceurs in Solenodon peradoxus attached by fibers to the approximated posterior edges of tibia and fibula. It lies in the popliteus muscle just below its origin from the femur. I have found no mention of such a bone in other Insectivora and it is not shown in Peters's figure of the skeleton of $\mathrm{S}$. cubanus. The greatest Jength of the tibia is $6.3 \mathrm{~mm}$., and of the fibula $58.5 \mathrm{~mm}$, or almost identically the same as the corresponding bones of st. cubanus.

The bones of the foot (Plite 8, figr. 16), aceording to Dobson, are in general like these of Centetes. They also appear to be essentially similar to those of the Erinacedae. These is, lowever, a rematrible development of the proximal portion of the entoduneiforme, whose ventral border is continued posteriorly so as to mect the antero-internat edge of the os calcis. This portion also articulates dorsally with the cutal surface of the astragalus and passes ventral to the navieulare which thus rests partly upen it. The last-naned is small and trapezoidal in shape, articulating with part of the distal face of the astragalus. The mesocuneiforme is about half the size of the ectocuneiforme and the two articulate with the second and third metatarsals respectively, as usual. The cuboid is large, and its expanded proximal end articulates with the os ealcis. The fourth metatarial is supported by its distal cnd, as likewise the cutal eorner of the fifth, which rests in part on the base of the former. There is a well developed prehallux of two separate bones. The more proximal is small and nearly round, about $1.5 \mathrm{~mm}$. in dianeter, at the ento-posterior edge of the naviculare. The more distal bone is flattencel, about $5.5 \mathrm{~mm}$. long, and slightly less than $2 \mathrm{~mm}$. distally where it reaches its greatest breadth. Peters has figured a sinular prehallux for the Cuban tolenodon.

The metatarsal of the hallux has a ventral outer projection at the base, that partially overlips the base of the second metatarsal from the plantar aspect. A much less imbrication is shown by the base of the second and the fifth metatarsals. No such development was noted in Gymmura and Erinaceus.

The three midlle digits, 2, 3, 4, are sulsequal in length; the fifth is shorter, and the first a trifle shorter still. This last has two phalanges, like the pollex. As in the manus, there are two small sesamoids at the base of all the proximal phalanges, and a minute median sesanoid rentrally at the last joint of each digit.

It remains to describe briefly the laryngeal and hyoid bones (Plate 7, fig. 3). 
These appear to be similar to those of s'. cubomus as figmred ly Peters ('64, Plate 2, fig. 11), and are well ossified. The thyroid is the largest, 1:3 mm. in greatest length. It is slightly more than half a complete ring and has at the anterion dorsal margin on each side a process for the articulation with the tips of the thyrohyals. Posteriorly, the dorsal margin is similarly produced to form processes articulating with the postcro-katcral margin of the cricoid. A low ridge arises about midway of the straight clorsal border and curves rentrally to the posterior edge. Nhere it on each sile is a minute foramen at the dorsal alge of the bone. On the lelt side in onr specimen there is in addition a minute foramen about 2 mon. anterior to the first. The thyrohyal of cach side has fused rentrally with the basihyal so that the three bones thus form a half ring, bowed back at first, then forward at the ventral side. The ceratolyals are appressed against the ventro-hateral margin of this ring. They are rather thick and about $4 \mathrm{~mm}$. in dorso-ventral length. Their dorsal border, and the edge of the thyrohyal adjacent, articulate on cach side with the epihyal, a broad but laterally flattened bone, that projects anterionly from this articulation. This in turn joins with the stylohyal, which is about '2 mm. longer, and mueh more rounded and slender. It joins the skull by a very short bony process that projects at nearly right angles from its proximal end. This process may represent a fused tympanohyal. The cricoid at its anterior end is clasper by the converging posterior processes of the thyroid and is a complete bony ring, with a postero-rlorsal extension. The vocal cords are attached by cartilage, one at each side from the anterior apex of this ring to its mid-rentral line, and pass forward as a delicate strand to a morlian attarhment just back of the anterior edge of the thyojel. The first tracheal ring is the broakest and fits into the posterior end of the cricoid, to which it is bound by muscle fihers. Peters states that in Solemolon cubamus the first nine tracheal rings are complete and that there are $21 \mathrm{in}$ all. In 5 . puradoxus the number is slightly more, 22 to 29, and all are incomplete dorsally. The chosest approximation is anteriorly where the two ends of the partial rings are about 2 mm. apart.

\section{VISCERAL ANATOMY.}

Digestive system.- The surface of the palate is marked by transwerse folds whose number seems commonly to be cight, onitting the ridge bounding the posterior cond. The first is a short transwerse ridge between the third inderens; the second is larger and pisses across at about the midulle of the cannines; the 
third begins at the anterion corner of the first premolar on cach sicle and is bowed forward; the fourth and the fifth arise on the palate at the base of the second and third premolars respectively; finally, the sixth, seventh, and eighth join the anterior edges of the first, second, and third molars respectively. The amount of bowing forward varies slightly. Brandt, in his original areount figures but seven, and Dr. J. A. Allen has recently deseribed the same number in the specomen at Now York. These may represent artual variations or, as seems probable, one of the folds may have become rolaxed and thus have disappeared through partial maceration. It is the smallest and anterionmost fold that is latcking in 1)r. Allen's specimen. Peters figures nine transverse folds for s. cubamus.

The tongue (Plate 9, fig. +) is long, namow, and tatpering. It is free at the

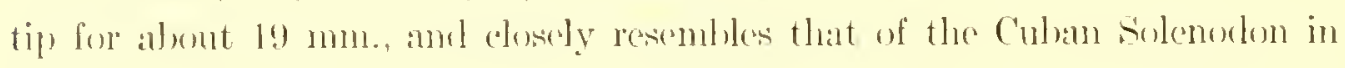
the character and distribution of the papillate. These are of three principal kincls: first, the fungiform papillae, that are scattered wer the surfare of the tongne from the museular prominences at its root, where they are most numerous, to the tip; they are white, and either round columnar projections or expanded at the top, and project eonspieunusly from the surface of the tongue: secondly, the cireumvallate papillae of which there are three, one circular and median, just posterior to the swellings at the ront of the tongue, and two oval, one on each side and slightly in advanee of the median papillas; in Cymnura there is no nedian circumvallate papilla; and thirdly under a lens, the surface of the tongue is seen to be thickly eovered with minute pointed filiform papillate, which become larger and flattened with appressed and backwardly directed points in the region of the circumvallate papillate. There is a slight median groove at the tip of the tongue.

The epiglot tis is short and cartilaginous, with a prominent median process anteriorly.

The salivary glands (Plate 6, fig. 1, p, s) are linge and prominent. The parotid is the most conspicuons and lies behind the masseter muscle and the ear, with a forwarl prokngation nearly to the ow dit in one specimen examined. Its duet is with difficulty traeed from a point below the ear, forward parallel to the roof of the mouth to about "pposite the first molar. The submaxillary gland consists of two portions as in Gymnura, one slightly more median, posterior to the angle of the jaw. Both are oval, smaller than the parotid, and slightly darker in color. In Centetes, this gland is in three divisions. Wharton's duct may be traced from the leeper portion of the gland near its center, forward, along the imer side of the ramus to the root of the tongue. 
The digestive traet itself is rery simple. The walls of the resophagus, as it enters the stomach, are thrown into about eight lomertudinal cormations that become confluent in part with the more numerous rugae of the lining of the stomach. These hatter onsist of about 16 elece ridges and more numerous shallow omes, rumber longitudinally. They become resluced to five or six thickened folds at the pylorus, where they end.

The stomach (Plate 9, fig. 7) in its undistended comdition, is subglobular and somewhat produced at the pyloric end as in Gymumat, though not to the extent figured by Dobson for Erinaceus. The cardiar portion shows no surh extrusion as in Erinuces europeus. Peters has figured the stomach of solenodon cubomus as a netrly globular organ with the pytorus very nea the oesophagus. This is somewhat different from its appearance in S. porudorus when undistended, and may not represent its true form. The greatest length of the stomach is about $37 \mathrm{nmm}$.. and the cardiac brealth alwout 2.5 $\mathrm{mm}$.

The small intestine merges with the large intestine so grarlually that it is mot possible to tell definitely where the two meet, but the thicker-walled portion following the list of the Peyer's patches is here taken to be the large intestine. The total length of the intestine from the pylows is ahout 1390 mm., or nearly four and one hatf times the length from the tip of the nose to the anus. In Gymmura it is about six times the length of head and budy. The total length of the small intestine, from the pylorus to the last Peyer's patch is $1200 \mathrm{~mm}$, and the large intestine $190 \mathrm{~mm}$. There is no indication of a caccum. The wall of the small intestine is seen muler a lens to be thiekly covered with villi which are arranged in more or less trunserse zig-zag lines. 'There are some seran Pryer's patehes. The first is wal, alout 8 hy sum., ancl situated 132 mm. from the pyloms. At about $185 \mathrm{~mm}$. after this are two smaller patches, one bohind the other. I fourth about 14 hy 8 mm., is found some 20.5 mum. posteriorly: a fifth after $250 \mathrm{~mm}$. more, and a sixth, 11 ly 5 mun. after 2020 num. The seventh amb last is a latge one alwut 1200) mm. from the pylorus.

The course of the intertine from the prones is lank alomg the right hody wall for about so mm., then across to the left side, and thonce again posterionly for some 25 mun., after which it turns ventrally and becomes much comboluted in the lower abdeminal regiom. It then passes forward along the left side of the boly and is again mueh convoluted below the stomich, whenee the large intestiue, after" a shent curve ("transverse eolom") runs directly back along the dorsal buty wall to the ants.

The strueture of the liver (Plate 9, figs. 3, 10) is comparatively simple. The 
organ is large and composed of three main lobes whose appearance is essentially like that in Centetes. The left lateral lobe is karge and rather oval, slightly less in breadth posteriorly than anteriorly. It is without secondary divisions. The right lateral tobe is of smaller diameter and subcylindrieal, consisting of two portions: the main lobe proper and the caudate division. The latter is large and of praxtically equal length with the main bobe into whose dorsal surface it is received by a deep groove. The sides of this groove enfold the caudate lobe so that its extcrior surface is continuous with that of the romded main lobe. The distal ends of the two appressed lobes are hollowed to receive the anterior and of the right kiency, which they thus together surround. In Cymmura the candate lobe is represented as long and narrow, and alone enfotding the end of the kidney. In Erinaceus the condition is much the same. The Spigelian tobe is very short and single, thus resembling that of Centetes, rather than that of the Erinaceidac in which it is generally larger in proportion and bifid. The contral lobe of the liver is practically entire except for a slight fissure at its left and, visible in ventral view, but covered dorsally by the gall blader. The dorsal surface is alepply grooved for the reecption of the pyriform gall bladkler, which is partially overhung by a projection of the substance of the liver. The suspensory ligament is attached along the modian portion of this central lobe for some $18 \mathrm{~mm}$. Posteriorly a small thread-like division of this ligament is given off to the tip of the secondary lobe separated off by the slight fissure previonsly mentioned at the left side of the main eentral bohe. The gall blakder is large and pyriform and its duet, abont $30 \mathrm{~mm}$. in length, opens into the small intestine in common with that of the panereas at about a centineter from the pyloms.

The pancereas (I'late 9 , fig. 7 ) is a large structure with very definite outline, and consists of two main lobes. The one is elongate, about is mm. in length by $15 \mathrm{in}$ width, and of a slightly reddish color. The other is subtriangular, and much more solid in consistency, becoming decidedly thickened at the free rounded apex. The duct is confluent with that from the gall blatder' at about $6 \mathrm{nmm}$. from the opening into the small intestine. There are no secondary pancreatic ducts. The great size and soliclity of the panercas are noteworthy in solenodon paradoxus. The slight and racemose structure figured for this organ in S. eubanus (Poters, '64, Plate 2, fig. 10) is quite different and may be the result of partial decomposition. In its bilobed character and the stoutness of the large triangular portion, the panceas of S. paradoxus secms to bear much resemblane to that of Chrysochloris.

Glands.- The spleen (Plate 9, fig. 5) is a large flattened mass of a dark red 
color attached hy delicate mesentery to the eardiace curvature of the ventral portion of the stomach. Its left end curves dorsally, slightly enfolding this part of the stomach, and forms a recurved lobe. When renoved and spread ont there is seen to be a slight constriction forming another teminal lobe at its right end. These lobes are not indirated by Peters in his drawing of the spleen of S. cubanus but otherise the two organs aplear similar.

There is a large mesenteric gland (Plate 9, fig. 6) above the reetum, in the dorsal mesentery, about a centimeter posterior to the left kidury. It is $1311 \mathrm{~m}$. long by $6.5 \mathrm{~mm}$. in greatest width, with slightly lobulate borter and a posterior noteh for the insertion of a vessel. Other smaller glands are present, 2 or 3 m $11 m$. long, srattered throughout the great mesentery, particularly in the region of the stomach, where cluse to the pylorus is a larese gland about 5 mms. long.

The thypoid glands (Plate 5, fig. 1,t) alre remarkably large, situated one on each side of the throat, posterior to the submaxillary glands. They are owal in

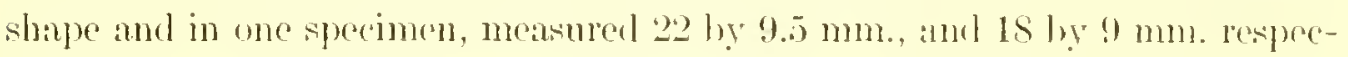
tively.

The thymus (I'ate 9, fig. 1, l) is a barge median gholular mass partially investing the base of the traebea ventrally just anterior to the heart. It consists of two rounded lobes, one on ench side, bound together by connertive tissue. The greatest median length of the mass is about $11 \mathrm{~mm}$.

In addition to these, thee is a glamdulat mass at the axilla and another just in front of the hip joint. The latter is rather large, and divided into two main masses, about 21 and $15 \mathrm{~mm}$. long respectively, and each about a third as wide as long. These, as stated by Poters, may be lymphatic glands, or possibly scent glands. They were discovered by Pory in fresh sprecimens of Solenodon cubanus. There are no anal glinds such as are found in Gymmura.

Fresh specimens show no skin glands. What 1)r. J. A. Allen (:08, p. 513, fig. 8) has figured as a "glandular surface of left thigh" is apparently the result of partial maceration of the hair follicles at that region. These are very large and conspicuous and might readily be mistaken for the openings of glands. In fresh specimens, however, there is no triee of such an area, but the cutire surface is well laired.

Mesenteries, - The great mesentery suspending the intestine from the dorsal body wall is continuous for practically the entire length of the gut, and shows no speeiat modification. A short narrow mesentery connects the liver and the small intestine and is continuous witls a dedicate membrane along the lesser eurvature of the stomach. 
Lungs.- The lungs (Plate 9, fig. 1) of Solenodon parudoxus are eapacious and the plemal cavity extends back as far as the 15th rib. At this point the diaphagm arises from the body wall and passes oblicpuely forward on each side, along the ventral elges of the sternal rilss to the base of the xiphisternum. The lobes of the left lung seem a trifle smaller than those of the right. The left lung is divided into three simple lobes of which the anteriomost is the least, the posteriomost the greatest. The right lung has in addition to the three main divisions corresponding to those of the other side, a well developed azygos lobe arising from the base of the large third lobe. The seeond lobe differs from that of the left side in having a transverse fissme by which it is divided into an anterior and a posterior portion. Peters figures no arygos lobe in the lungs of S. cubame, and the left midlle lobe seems to be more elongated transweredy. Apprently s. pretadoxus resentules Centetes in the character of the lung. Erinaceus is remarkable in having a simple, undivided left lumg and greatly elongated azygos lobe. In Ciymmura and Chrysochloris the left lmog is divided into two bohes and the azyos lobe is more like that of s. purarloxus, in which a further step has been taken by the development of a third lobe at the anterior end of the left long. The lomgs of Potamogale are described as essentially similar to those of Centetes.

Heent and its ressels- - The ventricks of the heart (Plate 9, fig. 2) form a romuled nass about $25 \mathrm{~mm}$. long. The right auride is noticeably larger than the loft, with thicker walls. The aorta arises as a large trmk from the right side of the heart, and at the point where it curves to the left side, sends off a large branch. This after about $5 \mathrm{~mm}$. divides into two large arteries, the more exterior of which is the riglat subelavian, the more interior the right cantid. The left carotil arises separately from the main trunk of the aorta close beyond the first large branch. The left subelavian likewise is eniven off imlependently just posterior to the last. The anta then passes posteriorly and is joined on the ental side ly the duetus arteriosus. The pulmonary arteries as misual come

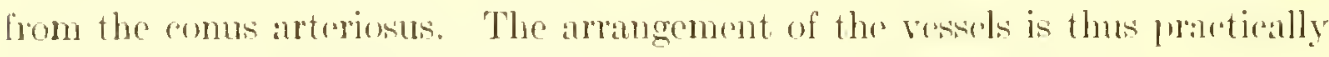
thr same as in Contetes, Potamogale, Chrysombloris, and Myogale.

Exeretory and genitul orguns.- The kidneys are similat in hoth sexes. They are large oval bolies in the usual position against the boly wall of the lumbar legion, that of the right side slightly anterior to that of the left. The ureters are slender tubes leading as usual to the blatkler on each side. The adrenal bodies are oval, each about one third the length of the kidney, and dosely appressed along its anteromedian border from the hilum nearly to the anterior end (Plate 9, fig. 9). 
The testes of the male are oval glands about 9 by $6 \mathrm{~mm}$. bound by a short and rather broad ligament $10 \mathrm{~mm}$. long, to the abdominal wall on either side a few millimeters above and anterior to the symphysis pubis. A long filamentous ligament likewise passes from the attached end of each testis to the posterior region of the arlrenal borly of each side. The testes are somewhat sunken into perineal sars, but still wholly intemal. The spermatic cords pass ventromedially and the vasa deferentia unite at the base of the bladder. The prostrate chands are small, oval, and united medially on the ventral sicle just eaudad of this point, much as in Centetes. No trace of Cowper's glands eould be discovered though their presence may have been overlooked. The penis is retractile and is caryed forward along the abdominal wall to about $2 \mathrm{~cm}$. from the anus. As stated by Dobson, this is an important difference in comparison with the condition found in the Centetinae and Potamogalinae in which the ponis is retractile within the cloaca. The testes, too, in the Centetinae, are found much farther forward.

The ovaries (Plate 9, fig. 8) in the adult female cxamined are small bodies abont $3 \mathrm{~mm}$. in length, dark brown in colos. They ar mainly suspended by the ovarian ligament, a thick filament extending along the anterior colge of each broad ligament of the uterus. The Fallopian tubes are short and convoluted, and pass at once into the cornua which are each about $15 \mathrm{~mm}$. long. The posterior position of the ovaries is again different from that found in the Centetidae in which they are (dose to the kidnars. The uterus is very long and narrow measuring about $40 \mathrm{~mm}$. in length. It is suspended hy the usual two ligaments: the boad on liganentum latum from the body wall to the cornua, and the round or ligamentum rutundum, that bounds the posterior free edge of a fold of the broad ligament, between which and the body wall there is thus formed a shallow divertirulum. The round ligament is inserted just caudad to the cornu of earh sicle, and passes to the body wall about midway on the anterior edge of the pubis. The genital organs of the Cuban Solenodon appear to resemble in essential points, those of the San Domingo species.

\section{BRAIN.}

The brain of Solenoton has been hitherto unknown. This organ was removed from one of the speeimens and though somewhat softened, it showed a number of interesting conditions (Plate 6, figs. 8, 9). Its general outline is much like that of the brain of Centetes as figured by Leche (:07, p. 102), with 
almost straight, posteriorly diverwing cerebral margins, instead of the outwardly bowed boundaries seen in Erinaceus, and Hemieentetes, or the eoncave outlines of Chrysochloris. The olfactory lobes are more oval, as in Hemicentetes (Leehe, :07, p. 102, fig. S7) and the constriction between them and the cerebral hemispheres is very shallow in eomparison with the eondition in the Centetidae. The cerebral lobes do not extend back so far, relatively, as in Centetes, for the optieus and post-opticus are visible in dorsal view, as is true also of Erinaceus. There is a single well marked lateral suleus on each of the hemispheres as in the latter, and in artition an ill defined suleus dorsal to this, which may have been the result of poor preservation. The cerebrum of Centetes is represented as cuite smooth. The cerebellum is longer in proportion than in Centetes, but otherwise much similar with a prominent vermis bounded posteriorly by a deep noteh, and with pointed lateral prolongations directed forwards. In median section, directly ventral to the center of the eerebelhm, two slicht transverse grooves mark off a woll defined pyramis and anterior to it a broader pons.

\section{PLEXUSES.}

The brachial plexus (Plate 6, figs. 7, 10) in Sulcnodon paradoxus is ehiefly made up of trunks from the sixth, seventh, and eighth eervical nerves and the first dorsal nerve. In one individual, a slender filament was present from the base of the fifth eerrical nerve passing posteriorly and receiving two minute threads from the sixth cervieal nerve. In Solenodon cubamus Dobson found the fifth eervical to enter into the plexus as a major element. More or less variation is to be expected in the details of the arrangement of the nerves, but the chief connections were nearly identieal in the specimens examined. The sixth nerve passes clistally as a single trunk with a large basal branch to the serenth cervical nere. In one instance this ennecting branch had the appearance of a fusion of a basal branch from both nerves, but in the other the dual nature of the connection was less clear. The lateral branch of the sixth nerve appears to correspond with that supplying the subseapular and teres museles. The sevently cervieal, in akdition to the short connection with the sixth, and a similar with the cighth, from the latter of which a eommon trunk passes off, has a mone listal bifureation, the posterior branch of which unites with a large branch from the cighth cervical. The main portion of the righth unites with the first dorsal nerve to form a single short trunk, which soon gives off a small posterior branch, the internal cutaneous. The plexus in solenodon is rather 
simple and resembles that of Potamogale and Chrysochloris in being composent of the last three cervical and first dorsal nerves, with the partial exception of the one instance mentioned in which a slender thread from the fifth eervical entered the complex. In Solenodon cubumus the fiftl cervical nerve seems to enter as a major element of the plexus and the same is true in the Centetidae. This fact is of interest in comnection with the additional dorsal vertebra in solenodon paradoxus as compared with the more specialized condition in S. cubanus.

The lumbo-sacral plexus (Plate 6, figs, 2, 3) of s. puradoxus was dissected in three individuals and found to differ from that figured by Dobson for $\mathrm{s}$. cubamus. The chief nerves composing the plexus are the second, third, and fourth lumbars, and the first sacral. In Centetes the second sacral in addition cuters into the complex, and this was found to be the case in one of the specimens of Solenodon paradoxus. The anterior crural and the obturator nerve arise mainly as branches of the second lumbar in two individuals while in a third they are from the third lumbar. In this specimen the great seiatic is nevertheless, nainly from the fourth lumbar as in the two other individuals. Dobson's figure of the lumbar plexus in s. cubanus shows the anterior crural and the ohturator arising together as in S. paradoxus, but from the fourth lumbar while the sciatic is composed of trunks from the first two sacrals. It is possible that confusion has arisen in numbering the several trunks, as otherwise the condition in the two species is the sante. In s. paradoxus all the hmbar norves virtually enter into the plexus by the first lumbar nerve sending a minute filament posteriorly to unite with the next following nerve as it issues from its foramen.

\section{SUMIMARY.}

In cxternal and cranial characters, Sulenodon paradoxus diffors very mark-

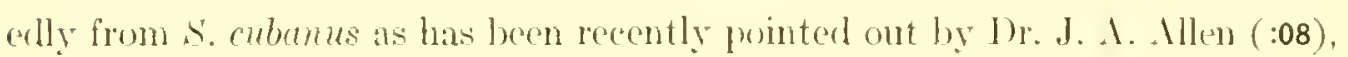
who has suggested that these differences may be eonsidered of sul generie value. In ricu of his careful summary, it is needless to repeat his mondusions here. It may be adeded, howerer, that the presence of a white nape spot is a fairly constant character of $s$. paradoxus, instead of an individual variation as soencel to be indieated by the specimens heretofore known. Further, the supposed glandular surface of the thighs is an appearance apparently due to peor preservation. The presence of long conrse hairs in the pelage in addition to the finer ones in S. parudoxus may indicate a step toward the sping condition of certain other Insectivora. 
The muscular anatomy of the two species is essentially similar althongh in case of the Cuban Solenodon, our knowledge is still somewhat imperfect, and rests almost wholly on the account by Dobson. This author fails to describe in S. cubarus a stylo-hyoid, though it may be present as in S. paradoxus. Other differences found in the latter as compared with Dobson's description of $\mathbf{S}$. cubams are: a single head to the biceps instead of two; a second head to the gluteus maximus arising from the ilium; slight differences in the insertion of the adductor longus; the mion of the soleus with gastrocnemius. Additional peculiarities are the inscrtion of tibialis anticus upon the entocuneiform instead of on the first metatarsal the insertion of peroneus longus upon metatarsals 1 and 5; the insertion of tibialis posticus upon the os calcis instead of upon the naviculare as in S. cubomus and other allied genera.

Ostcologieal differences beyond those emphasized by previous writers who have compared the skulls only, are: 16 instead of 15 dorsal vertebrae and thus an additional rib in S. puradoxus; one less segment to the sternum and a differently shaped xiphisternum; the separation of the radiate and the intermedium, which are satel by Dobson to be fused in S. cubanus; the distal fusion of the tihia and fibula, describerl as separate in S. cubumes. The proximal expansion of the entocunciforme to articulate ventrally with the anterior end of the os calcis is also a peculiarity not previously noted, though it may be similarly developed in the Cuban animal. The number of sacrals is probably the same in both species, since the fifth sacral figured by Peters for the latter, seems to be a fused caudal.

Other differences are noted in the visecral amatomy, such as the number of palatal rugae, which are normally cight in mumber, whereas nine are figured by Peters for S. cubonus; the presence of a lounded azyoges lobe to the right lung is not noted by l'etris, and his figures of the stomach and pancreas show slight differences that nay be in part due to poor preservation. 'The Cuban solenodon appears further to differ from s. paradoxus in that the fifth aevical nerve enters as a major alement into the brabial plexus. The plexuses, however, are subject to some slight variation, and additional specimens might show that this is not a constant difference.

Among the less specialized Insectivora, characterized by tritubercular molars, the two sipecies of Solenodon possess characters that abundantly warrant their separation as a fanily, as has been emphasized hy previous writers. Undoubtedly their pusition is near the Centetidae, from which they differ in a number of specialized characters, as the position of the penis, the differentiation 
of the teeth, the development of the smont, the ankylosis of tibial and fibula (at last in s. permdoxus). On the other hand solenodom possesses many generalized rharacters in common with Centetes, Potamogale, Gymmura, and even Myogale, the two latter of which are the most generalizerl members of their respective fantilies. Leche (:07) is douthless correct in making Pot anogale the representative of a subfanily (Potamogalinare) of Centeticlac, since the loss of elavieles and certain other peculiarities usually emphlatized ats distinctive, are probalbly the result of alaptation to an aquatic existence, while the general simplicity of strueture and the common anal and genital opening certainly ally it elosely to the Centetinate. On the other hand, Potamogale bears comsiderable superficial resemblance to Solenorlon and Myogale in the form of the skull and tecth, and it seems probahle that all three represent diverent lines of deseent from some common stock. 


\section{IITERATURE.}

ALLEN, I. I.

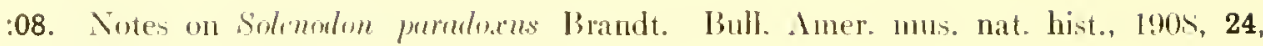
p. $517-517$, pls. $28-33$.

Binanit, J. F.

'33. De Solenodonte, novo mammalimn insertivormm grenere. Mém. Acad. imp. sci.

St. P'étersbourg, 1633, ser. 4, 2, 1. 459-47s, pls. 1, 2. Also separite', 1. 1-20, pls. 1, 2. Dubsox, (i. E.

'82-'90. A monograph of the Insectivora, systematic and anatomical. London, 18521890,4 to, is +172 y., 28 pls.

Giregoliy, W. K.

:10. 'The orders of mammals. Bull. Aner. mus, nat. hist., 1910, 27, p. 1-524. LeCHE, II

:02. Zur entwicklungsureschichte des zalnusstems der sängethicre, zugleich ein beitrag zur stammesceschichte dieser thiergrupe. Zweiter theil: Phylogenie. Exstes heft: Die familie der Erinaceidae. Zoologrica, 1902, part 37, 104 p'p., 4 pls., so text-firs.

:07. Zur entwieklungsereschidhte des zahnsystems der singetiere. Zweiter Teil: Plyylogenie. Zweites Heft: Die fimilien ale Centetidae, solenodontidae nud Chrysochloridae. Zoologica, 1907, part 4!, 158 pp., 4 pls., 108 text-fige.

Pinsine, l', G.

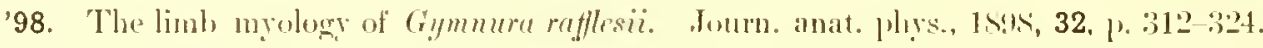
I'PTER, W.

'64. Teber die sibugethier-gattungr Solenodon. Ahl. Kön. akad. wissensels. Berlin, Poey, F. $186: 3,186.4$, ,. 1-2?, pls. 1-3.

'51. Memorias sobre la historia natural de la isla de (Muba (on Solenolon cubanus). IIakna, $1851,1,1.23-41,11.1$.

V'ErinLL, A. H.

:07. Notes on the habits and external chararters of the Solenodon of San Domingo (Sinlenodon preadoxus). Amur. jonm. sei., ser. 4, 24, 1. 55-57, 1 fier. Also Ann. mag. nat. hist., 1907 , ser. 7,20 , p. $68-70$, pl. 4. 
EAPLANATION OF PLATES. 


\section{PIATE 1.}

Fig. 1.- Toung female three days oll. $\times 1 \frac{1}{5}$.

Fig. 2.- Young female with hairy coat complete. About $\frac{2}{3}$ natural size. 
-
L
$a$
$a$
$z$
0
0
0
$z$
z
0
0
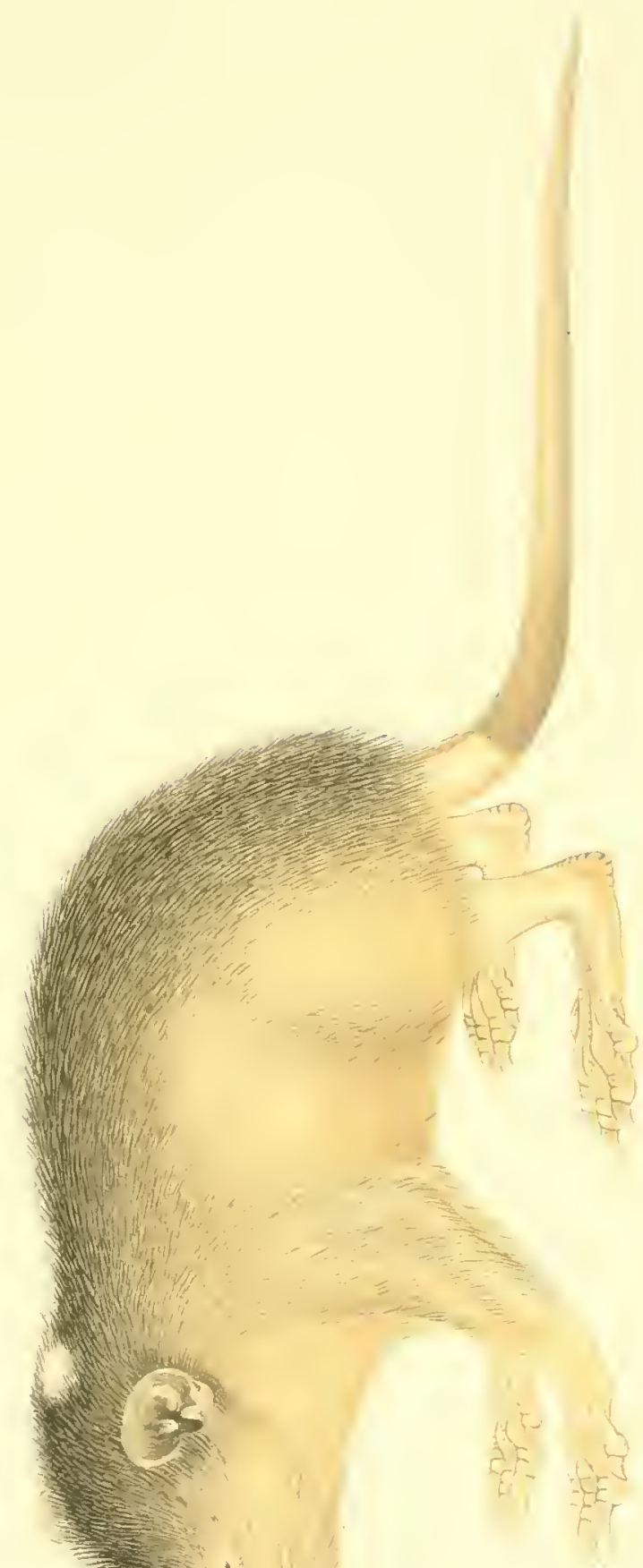

PLATE 2

Adult male in the rufous phase. About $\frac{1}{2}$ natural size. 
0
$\omega$
$a$
$a$
$z$
0
0
0
$z$
$u$
0
$u$

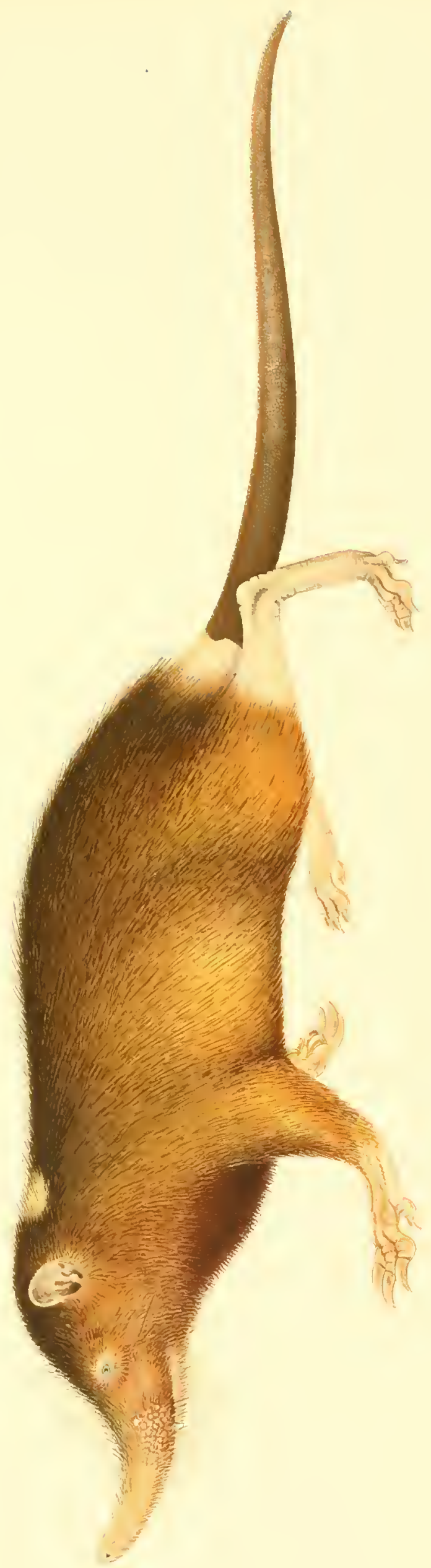



PLATE 3

Aclult female in the pale phase. Nhout natural size. 
m
L
J
0
$z$
0
0
0
$z$
0
0
in

\begin{tabular}{l}
$\overrightarrow{1}$ \\
0 \\
0 \\
$N$ \\
$a$ \\
$\Sigma$ \\
0 \\
$U$ \\
$n$ \\
$D$ \\
$\Sigma$ \\
$\Sigma$ \\
\hline$J$
\end{tabular}

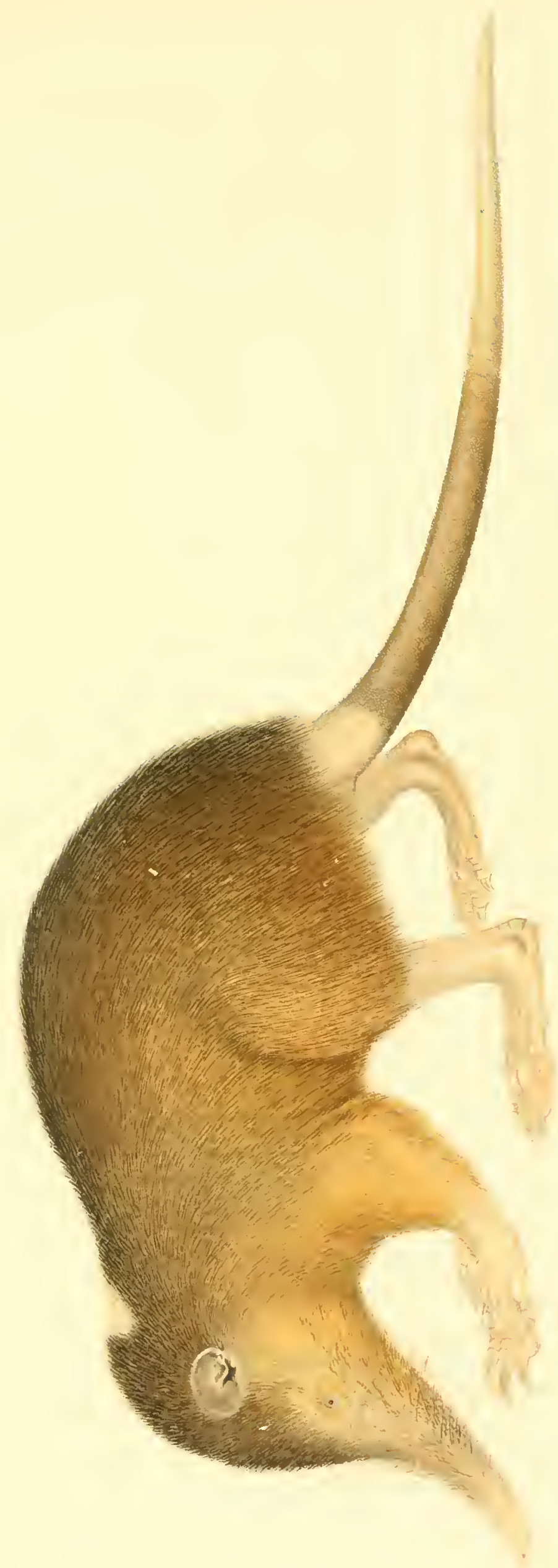




\section{,}



PLATE 4

Fig. 1, - Superficial muceles of the thorax. a, clavo-trapezins; b, supracervico-eutanens; $c$, acromiotrapezius; d, spino-trapezius; $e$, dorso-cuticularis; $f$, latisimus clorsi; $g$, epitrochlearis; $h$, treses. $\times 1$.

Fig. 2. Museles of the hind lege, ventral view, $a$, rentus femoris; $b$, vastus interuus; $r$, arlductor longus; $d$, semimemhranosus; $r$, adductor lorevis; $f_{1}$ semitendinosus; $g$, gracilis; $h$, puadratus

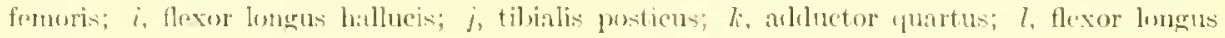
digitorum pudis; m, aulinctor maguus; $n$, pectineus; o, pows magnus; p, psoas parvus. $\times 1$ 

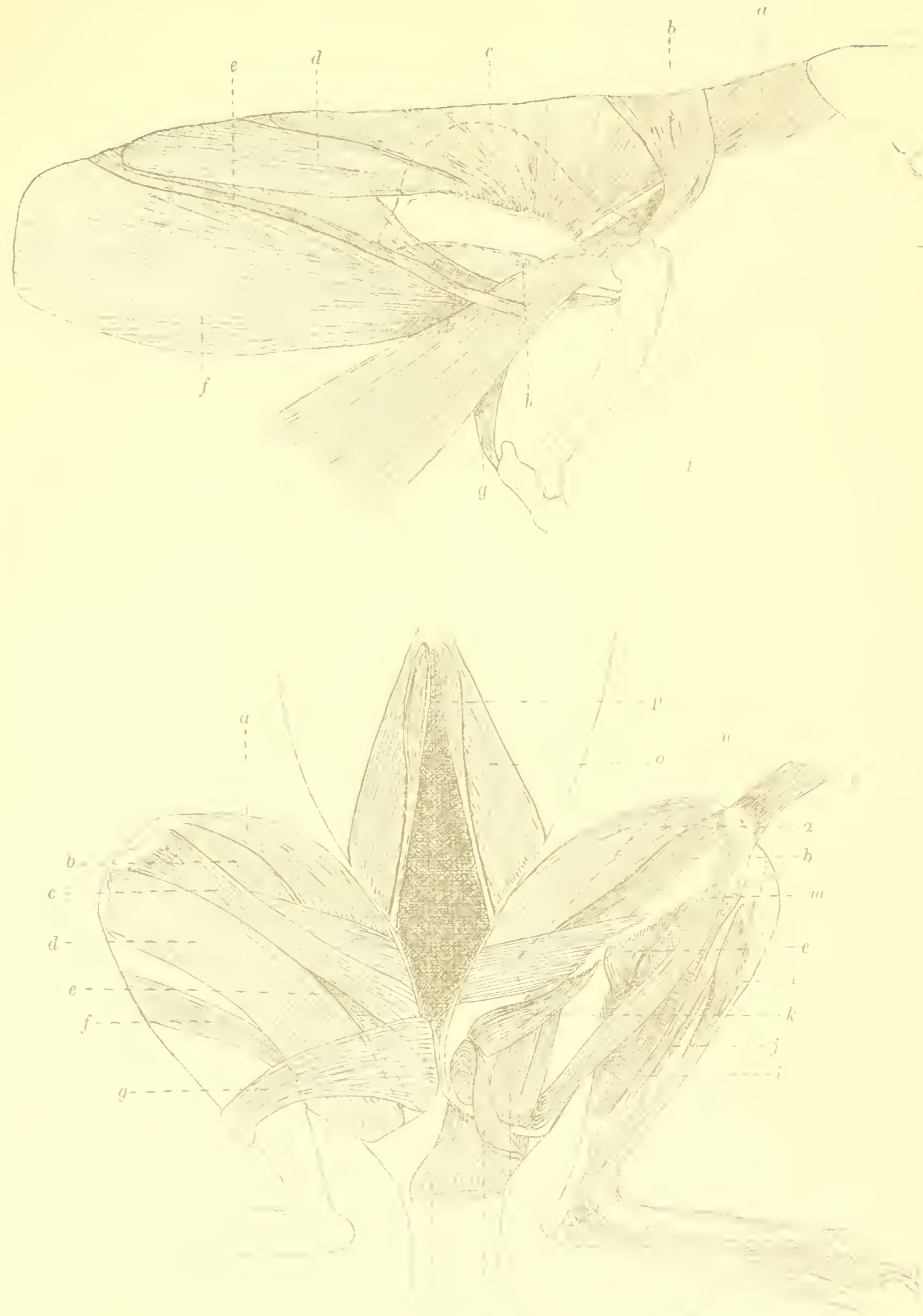

PLATE 5.

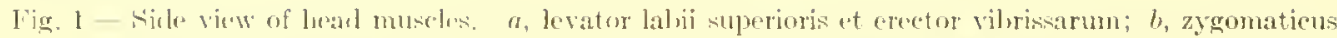

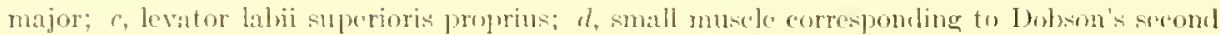

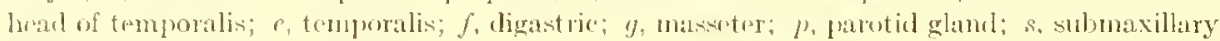
glamel: 1 , thymil $\times 1$

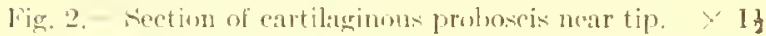

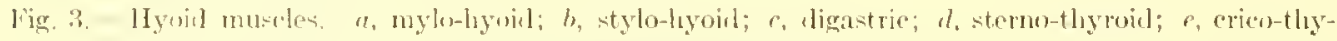
roisl; $f$, sterbo-hyorid; q, manul, riom of the stermum. $\times 1$

Fig. 1- l'ectoral and rervieal museles. a, levator elavieulae; b, oreipito-scapularis; $r$, clavieular

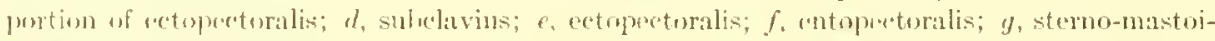
dlus: h, revillo-mastoidens. $\times 1$.

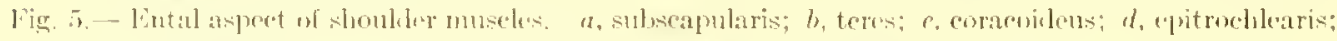

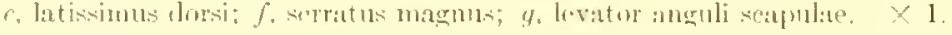

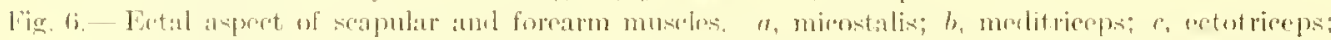

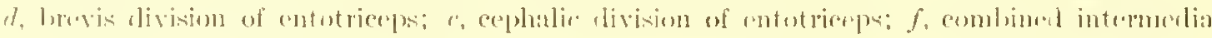

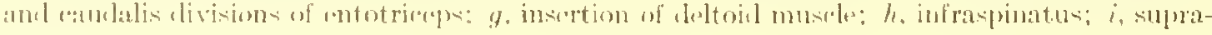
spinatuk. $\because 1$. 

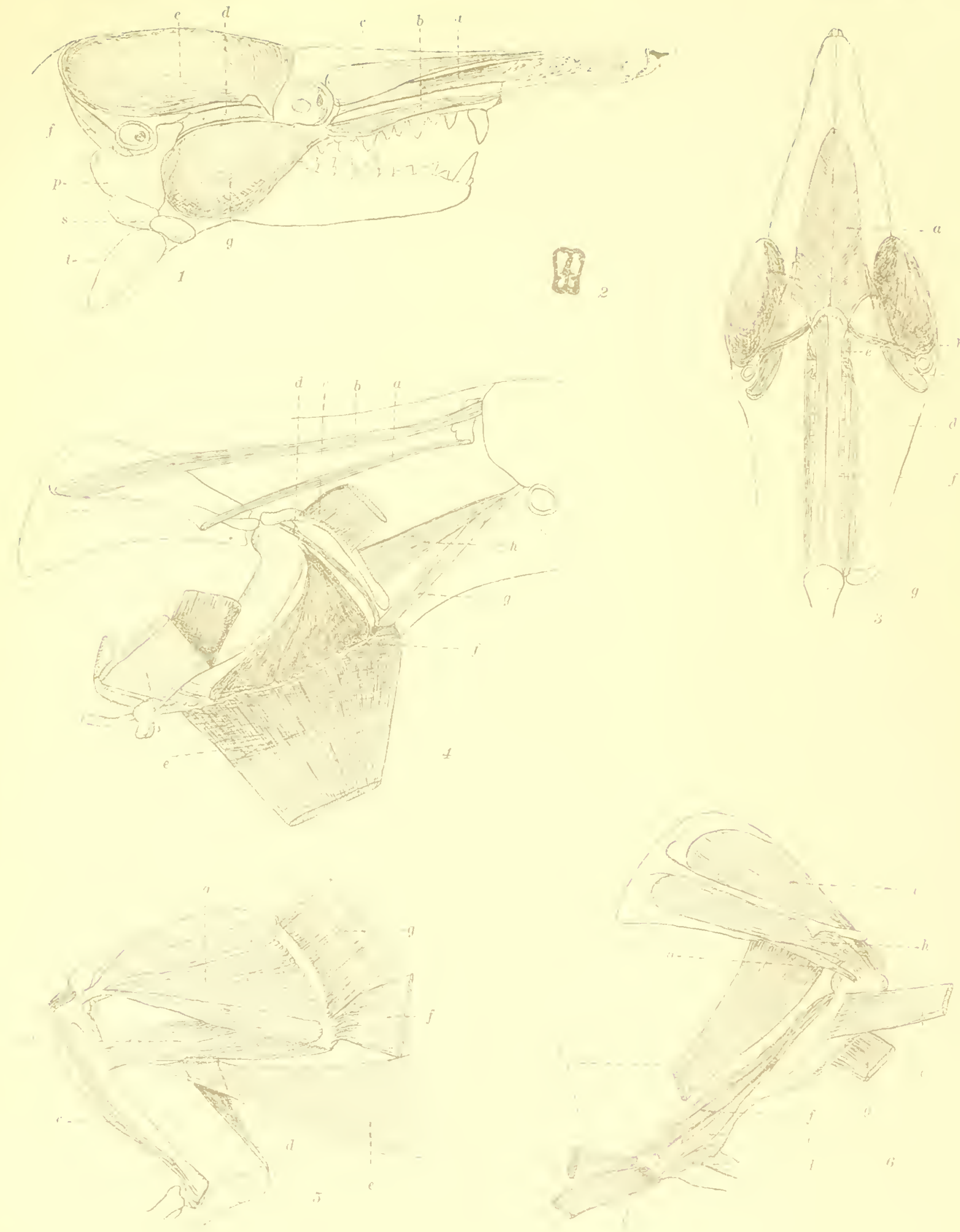


PL.ITE B.

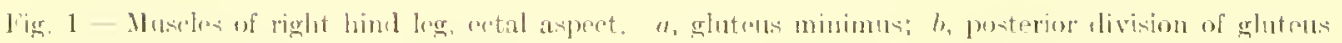

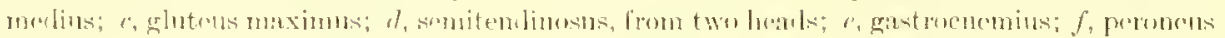

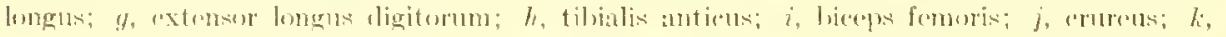

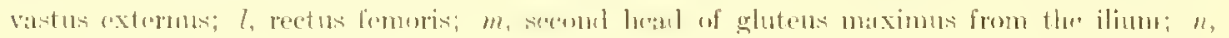
ghut ons mulins. $\times 1$

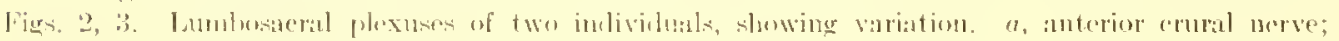
"olituratur; s, sitiatir. $\times 1$

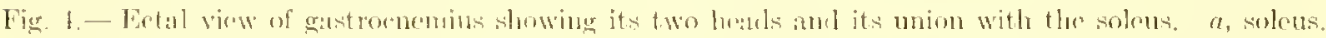
$\times 1$

Fig. 5.- Forcatrm muscles from dorsal aspert. u, extensor ligitorum rommunis; b, cxtensoles badialis longior ef brevior; c, pronator teres; $d$, extensor ussis metararpi pollicis; e, extenson carpi ulumis: $f$, indicator"; $\eta$, extensor mininu digiti. $\times 1$.

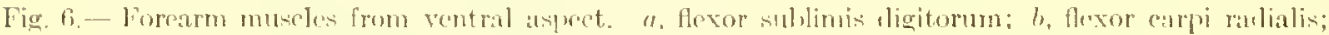
c. Hexor carpi ulnaris; d, llexor prolunclus digitorum, $x t$.

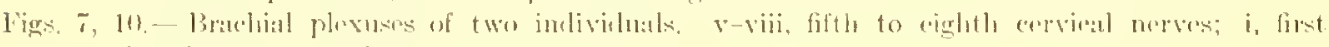
larkal norver. $\times$ illout 3 .

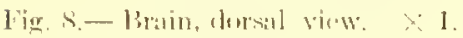

Fig. 9-Brain, sagittal section. $\times 1$. 


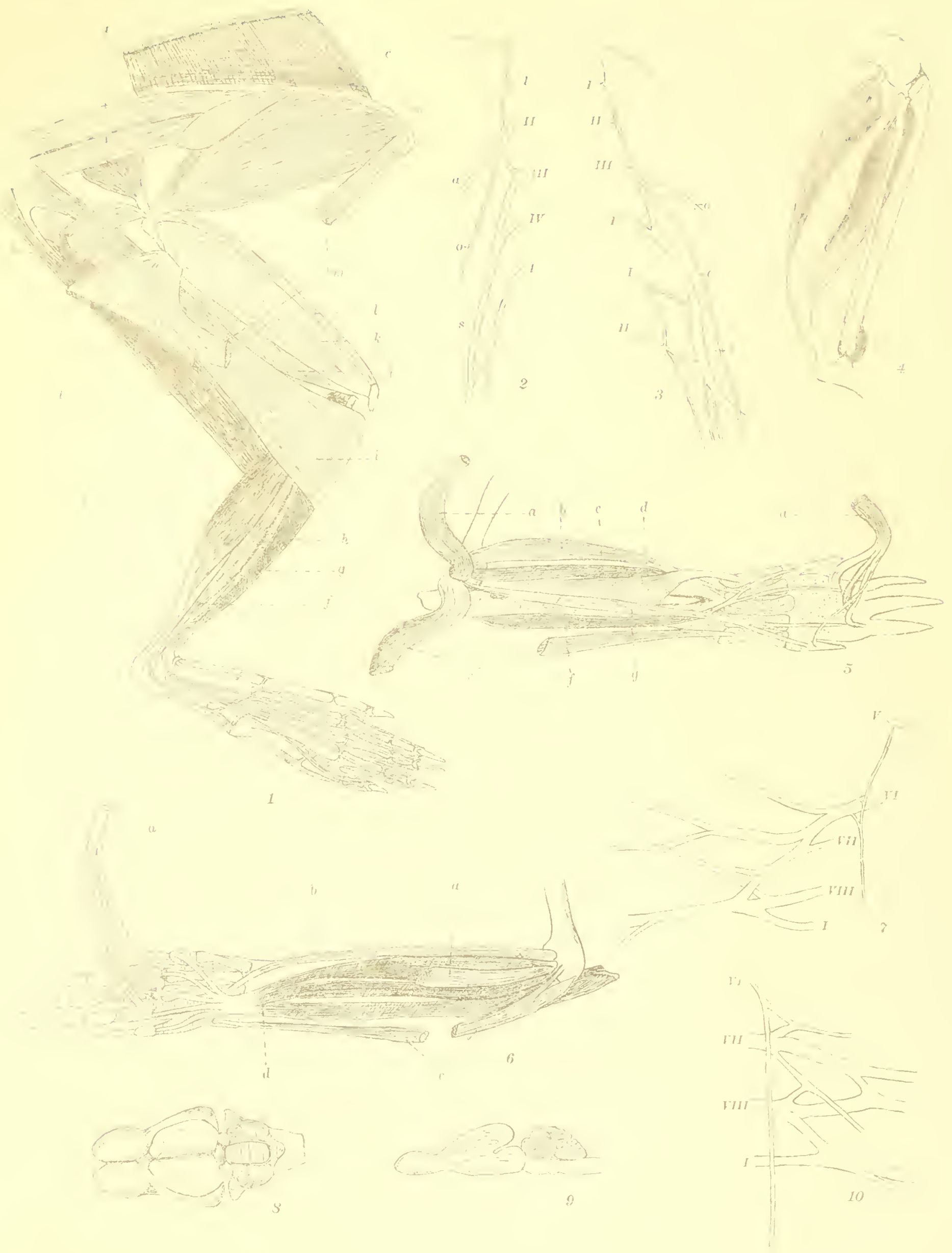




III.ITI: 7 .

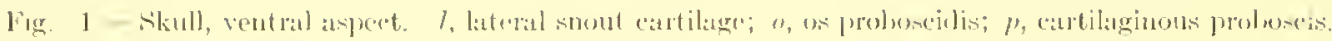
$\times 1$.

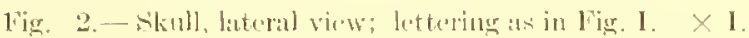

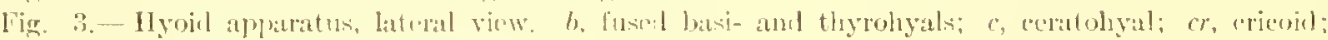

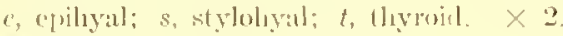

Fig. 1.- Athats, clorsil vicw. X 1 .

Fig. 5.- Athas, interior view. $\times 1$.

Fig. 6, - Right ramus, lateral asperet. $\times 1$

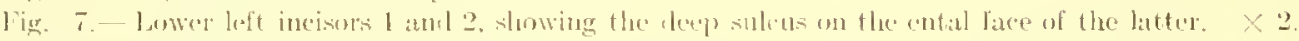

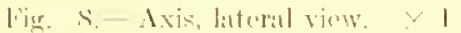

lig. 9.- Axis, anterior view. $\times 1$.

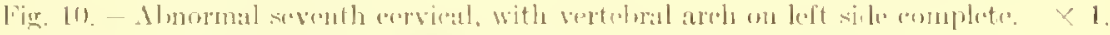

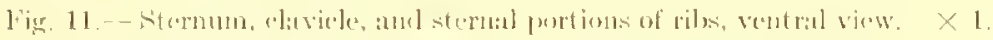

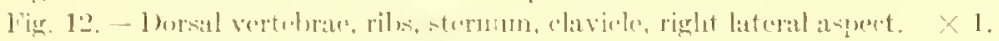

Fig. 1:- lumbar vertedrace, right bateral viow. $\times 1$

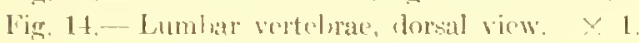



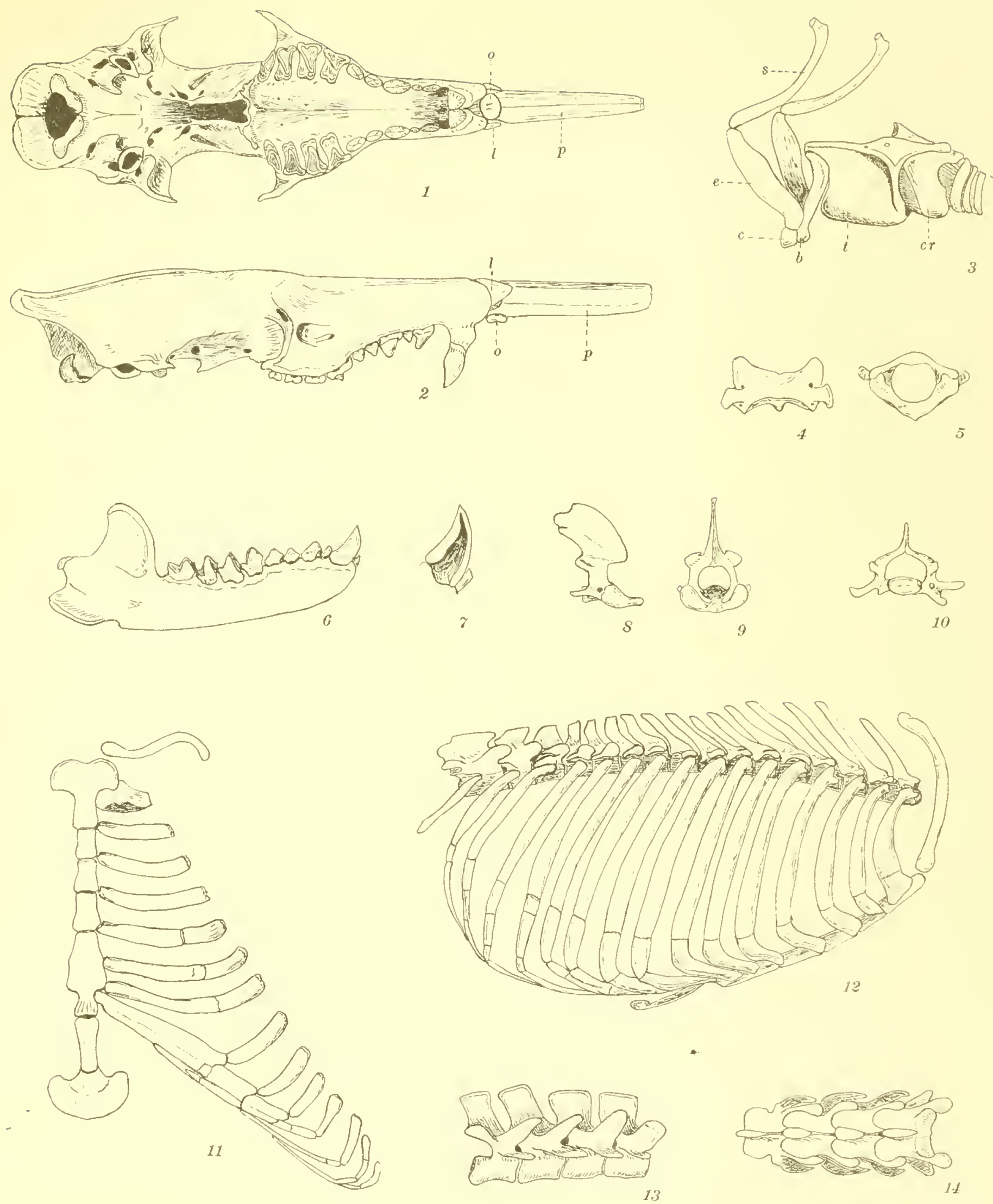




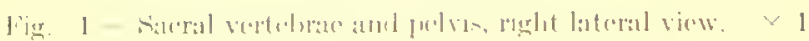

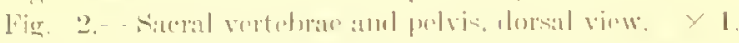

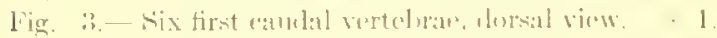

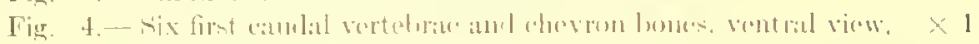

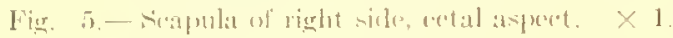

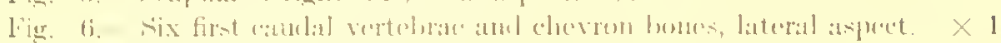

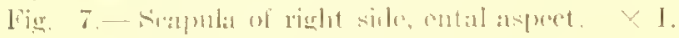

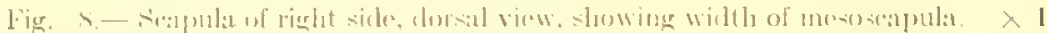

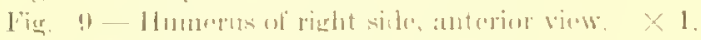

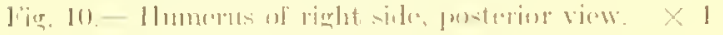

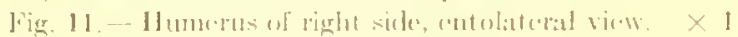

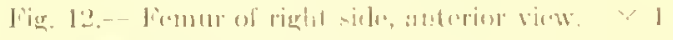

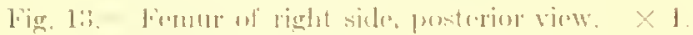

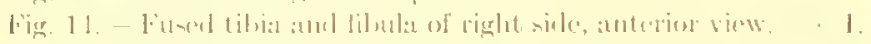

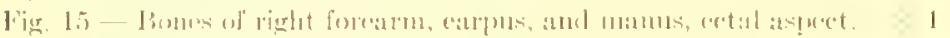

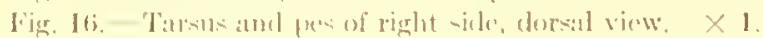



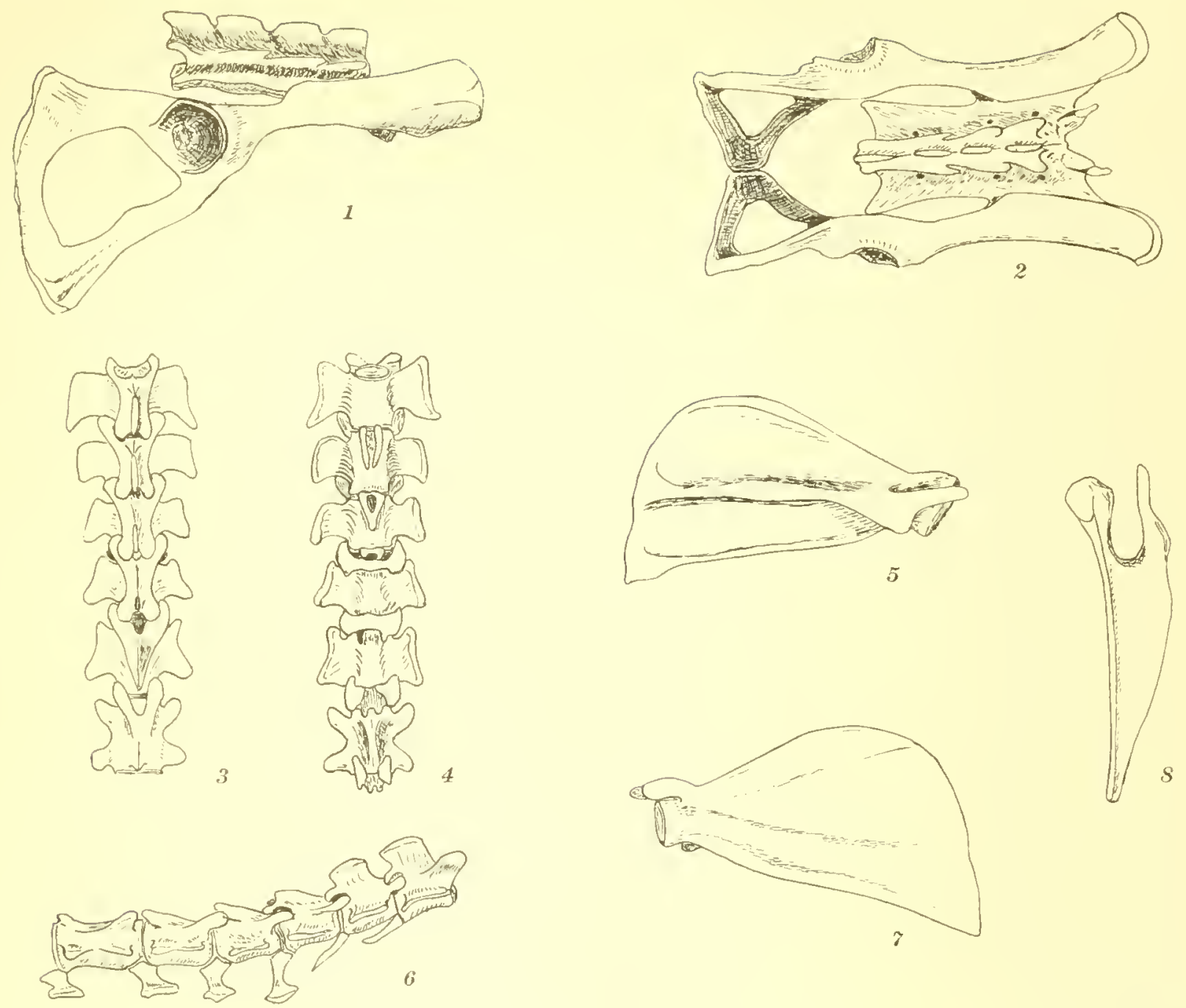

S
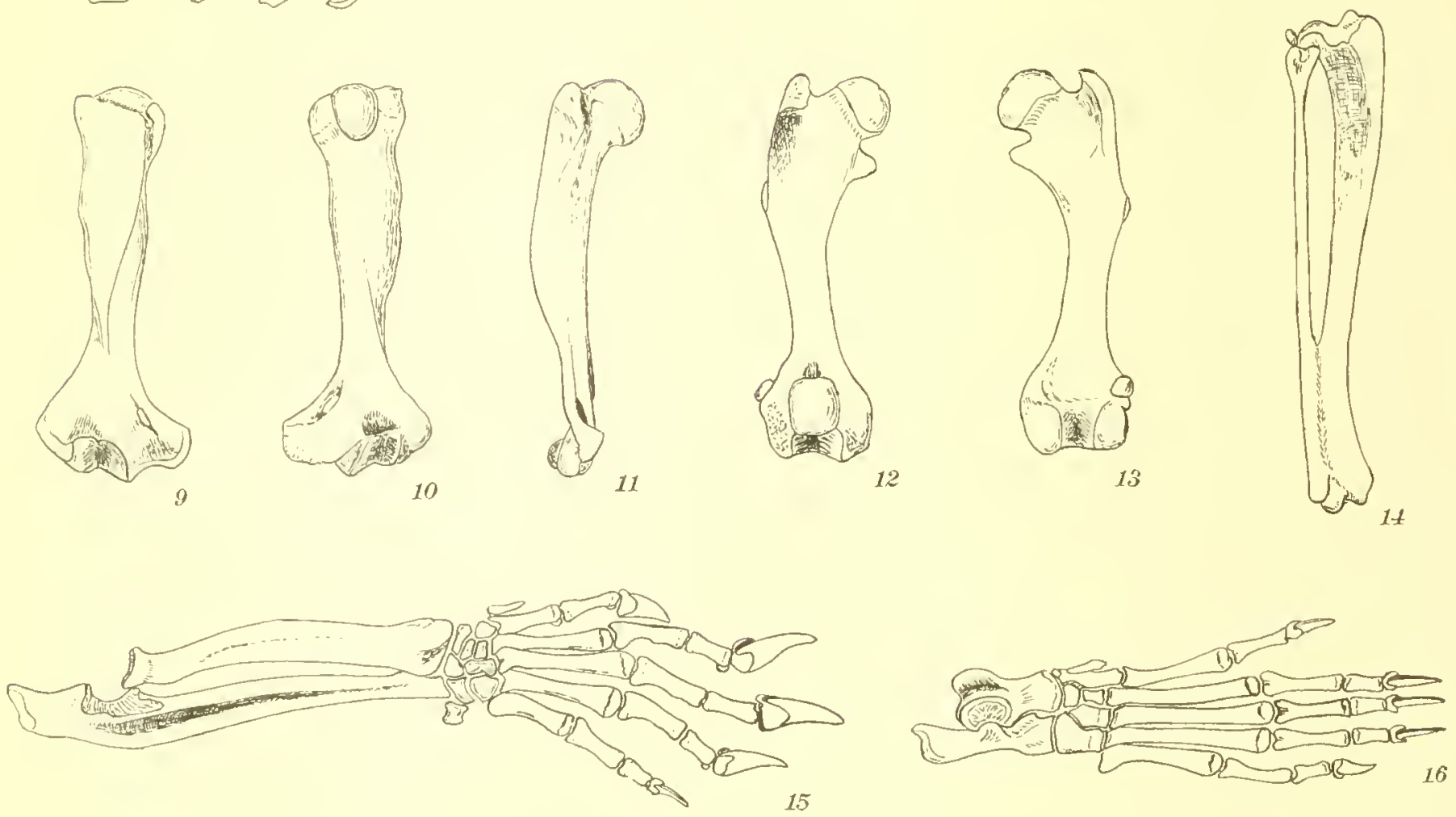


PLATE 9.

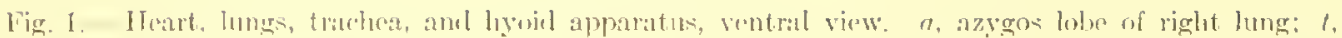
thymis. $: 1$.

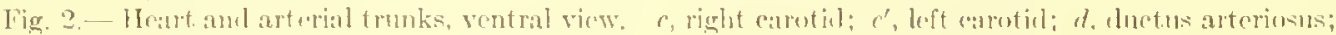

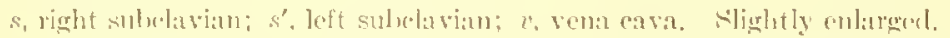

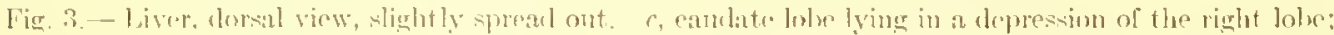

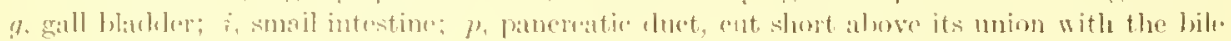
luet; s, sperigelian lohe. $\times 1$.

Fig. 1- Tnugue, rorral view. $\times 1$

Fig. 5.- 1 latre splen, somwhat spreal ont, $\times 1$.

Fig. 6.- Larere gland in flue mesentery dorsa! to restom. $\times 1$.

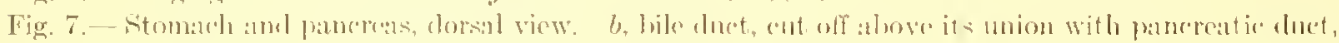

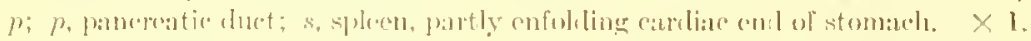

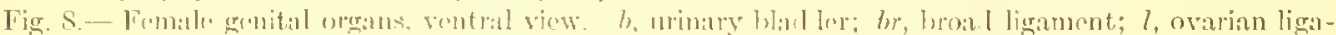
ment; n, warry r. rund ligament; $u$, uterus. $\times 1$.

Fig. 9- Male erental and "xeretory urgans, ventral viow, r, comral museles: li, kidney; l, ligament;

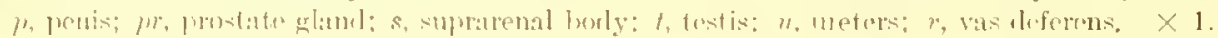

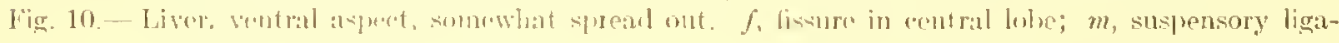
ment. $\because$ 


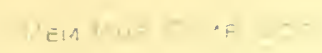

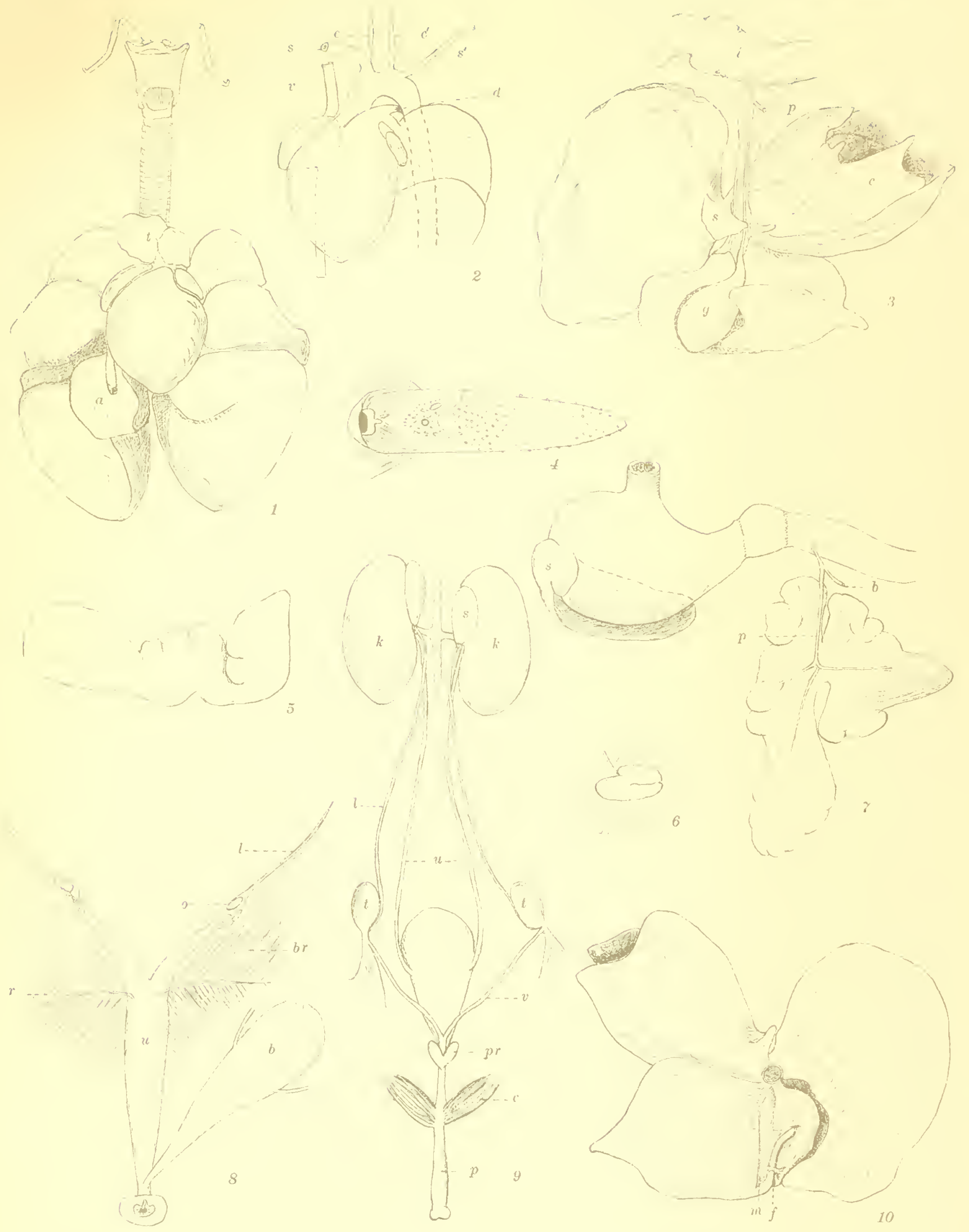


